\title{
Red-Emissive Cell-Penetrating Polymer Dots Exhibiting Thermally Activated Delayed Fluorescence for Cellular Imaging
}

By Cheyenne J. Christopherson ${ }^{\dagger}$, Nathan R. Paisley ${ }^{\dagger}$, Zhujun Xiao, W. Russ Algar* and Zachary M. Hudson*

${ }^{\dagger}$ These authors contributed equally to this work.

Department of Chemistry, The University of British Columbia, 2036 Main Mall, Vancouver, British Columbia, Canada, V6T 1 Z1.

Tel: +1-604-822-3266; Fax: +1-604-822-2847; e-mail: algar@chem.ubc.ca, zhudson@chem.ubc.ca.

\section{Table of Contents}

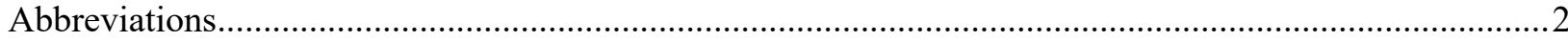

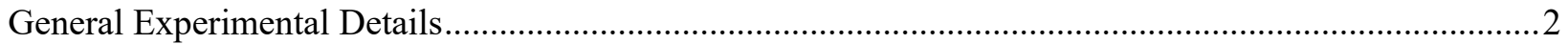

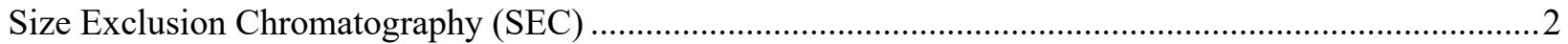

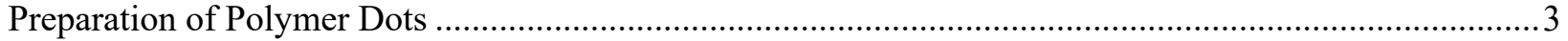

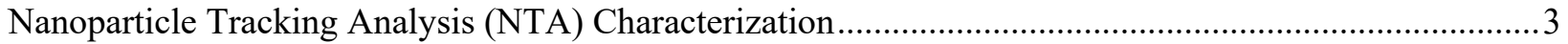

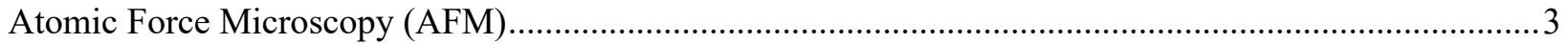

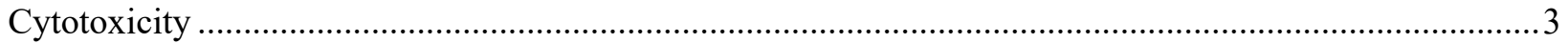

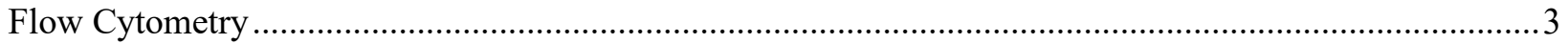

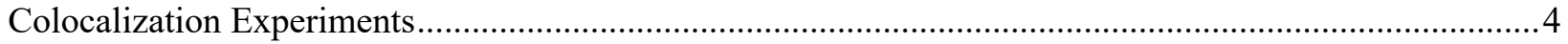

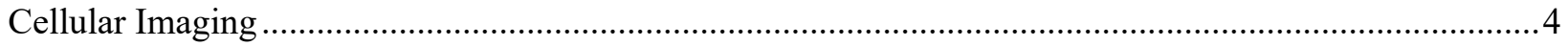

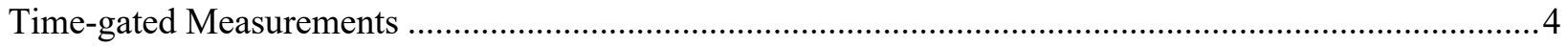

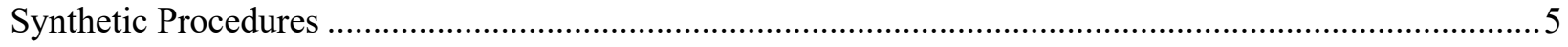

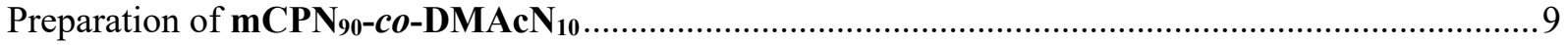

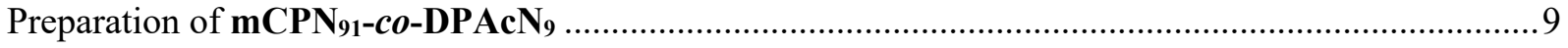

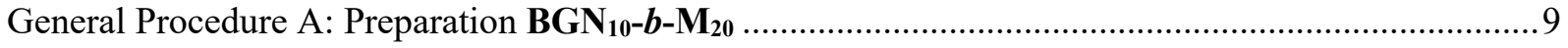

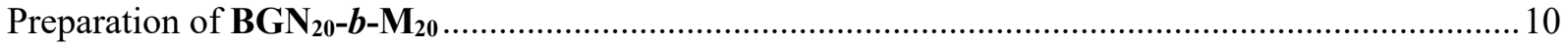

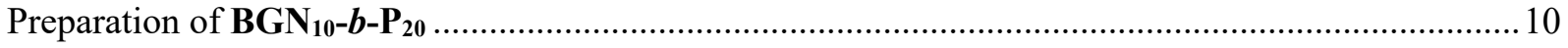

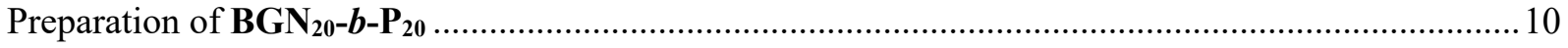

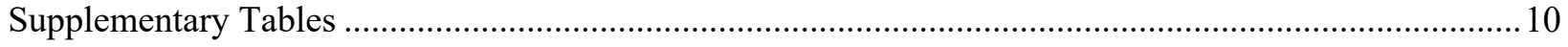

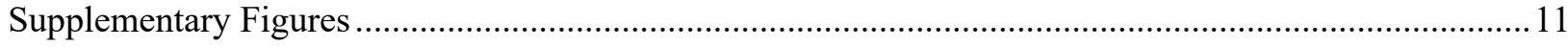

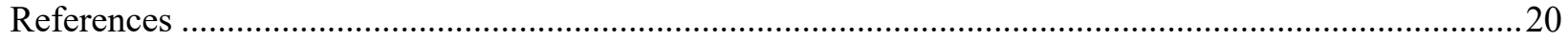




\section{Abbreviations}

AFM: atomic force microscopy

CHO: Chinese hamster ovary

DCC: $N, N$ '-dicyclohexylcarbodiimide

DIC: differential interference channel

DMAP: dimethylaminopyridine

DMEM: Dulbecco's modified eagle medium

GPC: gel permeation chromatography

Grubbs G3: [1,3-Bis(2,4,6-trimethylphenyl)-2-imidazolidinylidene]dichloro(benzylidene)bis(3 -

bromopyridine)ruthenium(II)

MCS: multi-channel scaling

MEM $\alpha$ : minimum essential medium $\alpha$

MTT: 3-(4,5-dimethylthiazol-2-yl)-2,5-diphenyltetrazolium bromide

NTA: nanoparticle tracking analysis

PBS: phosphate buffered saline

SBR: signal-to-background ratio

SNR: signal-to-noise ratio

TCSPC: time-correlated single photon counting

\section{General Experimental Details}

All reactions and manipulations were carried out under a nitrogen atmosphere using standard Schlenk or glovebox techniques unless otherwise stated. Dry solvents were obtained from Sigma-Aldrich, dried using an Innovative Technologies Inc. solvent purification system, and stored under a nitrogen atmosphere unless otherwise stated. Dry $\mathrm{CH}_{2} \mathrm{Cl}_{2}$ was obtained from Sigma-Aldrich and freshly distilled over $\mathrm{P}_{2} \mathrm{O}_{5}$ before use. All reagents were obtained from Sigma-Aldrich, TCI, or Oakwood Chemicals and used as received. All ${ }^{1} \mathrm{H}$ and ${ }^{13} \mathrm{C}\left\{{ }^{1} \mathrm{H}\right\}$ NMR spectra were obtained on a Bruker AVANCE $400 \mathrm{MHz}$ spectrometer. Absorbance measurements were made on a Cary 60 spectrometer and fluorescence measurements were made on an Edinburgh Instruments FS5 spectrofluorometer. Absolute PL quantum yields were determined using an Edinburgh Instruments SC-30 Integrating Sphere Module. Lifetime measurements were collected using time-correlated single photo counting (TCSPC) or multichannel scaling (MCS) on an Edinburgh Instruments FS5 spectrofluorometer equipped with a TCSPC diode $(313 \mathrm{~nm})$ and a Xe microflash lamp. Toluene was used as the solvent for all photophysical experiments unless otherwise stated. Mass spectra were collected on a Katros MS-50 mass spectrometer. Cell images were acquired with an Olympus IX83 inverted epifluorescence microscope. The research-grade microscope was equipped with an X-Cite 120XL metal-halide light source (Excelitas Technologies, Mississauga, ON, Canada), a white-LED transmitted light source, an Orca-Flash 4.0 V2 sCMOS camera (C11440; Hamamatsu Photonics, Hamamatsu, SZK, Japan), motorized filter wheels (Sutter Instruments, Novato, CA), and MetaMorph/MetaFluor software (Molecular Devices, Sunnyvale, CA). CHO, HeLa and HepG2 cells were obtained from UBC Chemistry bioservices.

1, ${ }^{1}$ NAI-THP, ${ }^{1} \mathbf{3},{ }^{2} 4,{ }^{3}$ and $\mathbf{~} \mathbf{C P}-\mathbf{O H}^{1}$ were prepared according to literature procedures. Their characterization matches the corresponding literature values; 3 and $\mathbf{4}$ were used without purification.

\section{Size Exclusion Chromatography (SEC)}

SEC experiments were conducted in chromatography-grade THF at concentrations of $0.5-2.0 \mathrm{mg} \mathrm{mL}^{-1}$ using a Malvern OMNISEC GPC instrument equipped with a Viscotek TGuard column (CLM3008), and Viscotek T3000 (CLM3003) and T6000 (CLM3006) GPC columns packed with porous poly(styrene-codivinylbenzene) particles regulated at $35^{\circ} \mathrm{C}$. Signal response was measured using a differential viscometer, differential refractive index, photodiode array, and light-scattering $\left(90^{\circ}\right.$ and $\left.7^{\circ}\right)$ detectors. The interdetector volume was calibrated using a single polystyrene standard with $M_{\mathrm{n}}=101,000$ and $Ð=1.04$. Molecular 
weight for $\mathbf{m C P N}$ copolymers was determined by triple detection $(\mathrm{d} n / \mathrm{d} c=0.259 \mathrm{in} \mathrm{THF})$. Molecular weight for the Boc-protected diblock copolymers was determined by triple detection for the $1^{\text {st }}$ block $(\mathrm{d} n / \mathrm{d} c=$ 0.0805 in THF).

\section{Preparation of Polymer Dots}

Polymer dot solutions were prepared by dissolving deprotected polymers $\mathbf{B G N}_{\mathbf{1 0}}-\boldsymbol{b}-\mathbf{M}_{\mathbf{2 0}}, \mathbf{B G N} \mathbf{-} \mathbf{b}-\boldsymbol{b}-\mathbf{M}_{\mathbf{2 0}}$, $\mathbf{B G N}_{10}-\boldsymbol{b}-\mathbf{P}_{\mathbf{2 0}}$, or $\mathbf{B G N}_{\mathbf{1 0}} \boldsymbol{b} \boldsymbol{b}-\mathbf{P}_{\mathbf{2 0}}$ in THF at a concentration of $1 \mathrm{mg} \mathrm{mL}^{-1}$. This solution was injected into 1 $\mathrm{mL}$ Milli-Q water under vigorous sonication. The THF was then fully removed under reduced pressure, such that the final concentration of polymer was $1 \mathrm{mg} \mathrm{mL}^{-1}$ in water. Polymer dot solutions were stored at $4{ }^{\circ} \mathrm{C}$ until use. These solutions were diluted with growth medium for cell studies (MEM- $\alpha$ for CHO and HeLa; DMEM for HepG2).

\section{Nanoparticle Tracking Analysis (NTA) Characterization}

The sizes of the Pdots were determined on a Nanoparticle Tracking Analyzer (Malvern NS300) instrument equipped with a 488 -nm peak wavelength laser, operating at a maximum power of $45 \mathrm{~mW}$. The Pdots were analyzed using scattering mode (no emission filter).

\section{Atomic Force Microscopy (AFM)}

Atomic force microscopy (AFM) images were obtained using an Asylum Instruments Cypher S AFM system in tapping mode at scan rates of $0.3 \mathrm{~Hz}$. Samples were prepared by spincoating aqueous solutions of $\mathbf{B G N}_{\mathbf{2 0}} \boldsymbol{- b}-\mathbf{M} \mathbf{M}_{\mathbf{2 0}}$ Pdots onto freshly cleaved highly-oriented pyrolytic graphite (HOPG) at $2500 \mathrm{rpm}$ for 30 $\mathrm{s}$ at concentrations of $\sim 0.01 \mathrm{mg} \mathrm{mL}^{-1}$. Samples were placed in a vacuum oven $\left(50{ }^{\circ} \mathrm{C}\right)$ for at least $15 \mathrm{~min}$ before images were obtained using Mikromasch HQ:NSC19/No Al probes, with typical resonance frequencies $\mathrm{f}=65 \mathrm{kHz}$ and spring constants $\mathrm{k}=0.5 \mathrm{~N} / \mathrm{m}$.

\section{Cytotoxicity}

Cell viability was measured in triplicate using a standard MTT assay. Cells were seeded in a 96-well plate ( $1.5 \times 10^{4}$ cells per well) in $100 \mu \mathrm{L}$ of growth medium and incubated for 24 hours at $37{ }^{\circ} \mathrm{C}$ in $5 \% \mathrm{CO}_{2}$ to allow for attachment. Polymer dot solutions, diluted to the desired concentrations with growth medium, were added $\left(100 \mu \mathrm{L}\right.$ per well) followed by incubation for 24 hours. Then, $50 \mu \mathrm{L}$ MTT $\left(2.5 \mathrm{mg} \mathrm{mL}^{-1}\right.$ in PBS) was added to each well, followed by incubation for 3 hours. The solution was removed from all wells, and $100 \mu \mathrm{L}$ DMSO was added. The absorbance at $570 \mathrm{~nm}$ of each well was measured on a Molecular Devices FilterMax F5 Multi-Mode Microplate Reader. All absorbance values were corrected for baseline absorbance. Cell viability was determined using Equation 1. The same procedure as above was used for testing cell viability after 1 hour, except 20,000 cells were plated per well, to approximate the number of cells that would be present after 48 hours.

$$
\text { Cell viability }(\%)=\frac{\text { Mean abs. incubated cells }}{\text { Mean abs. control cells }} \times 100 \%
$$

\section{Flow Cytometry}

The efficiency of cellular uptake was measured using flow cytometry. Cells were seeded in a 12-well plate $\left(1.0 \times 10^{5}\right.$ cells $\mathrm{mL}^{-1} ; 1 \mathrm{~mL}$ per well) and incubated at $37^{\circ} \mathrm{C}$ in $5 \% \mathrm{CO}_{2}$ overnight to allow for attachment. Then, polymer dot solutions, diluted to the desired concentration with growth medium, were added $(1 \mathrm{~mL}$ per well), followed by incubation for 30 minutes. The cells were then washed $3 x$ with $10 \%$ medium in PBS, collected with trypsin, and washed $2 \mathrm{x}$ further to remove excess trypsin. Cells were stored as a single-cell suspension in $10 \%$ medium in PBS at $4{ }^{\circ} \mathrm{C}$ until measurement (cells were measured within 2 hours of collecting). The mean fluorescence of cells was measured on a Beckman Coulter CytoFLEX LX flow 
cytometer at a rate of $30 \mu \mathrm{L} \mathrm{min}{ }^{-1}$ and compared to the mean fluorescence of control cells. Control cells were subjected to the same washing steps as incubated cells.

\section{Colocalization Experiments}

Cells were seeded on gelatin-coated cover slips inside a 12 -well plate $\left(50,000\right.$ cells $\mathrm{mL}^{-1} ; 1 \mathrm{~mL}$ per well) and incubated at $37{ }^{\circ} \mathrm{C}$ in $5 \% \mathrm{CO}_{2}$ overnight to allow for attachment. Then, cells were incubated with polymer dot solutions $\left(25 \mu \mathrm{g} \mathrm{mL}{ }^{-1}\right)$ and Lysotracker Blue DND-22 $(50 \mathrm{nM})$ for 30 minutes at $37{ }^{\circ} \mathrm{C}$ in $5 \%$ $\mathrm{CO}_{2}$. All growth medium was subsequently removed, and the cells were washed $3 \mathrm{x}$ with PBS. They were then fixed with $4 \% \mathrm{w} / \mathrm{v}$ paraformaldehyde in PBS at room temperature for 15 minutes, followed by 3 washings with PBS to remove excess paraformaldehyde. The coverslips were then transferred onto microscope slides for imaging. Control samples were subjected to the same washing procedures as test samples.

For colocalization experiments, a $350 / 50 \mathrm{~nm}$ bandpass excitation filter, a dichroic mirror with $470 \mathrm{~nm}$ transmission cut-on wavelength, a $550 \mathrm{~nm}$ longpass emission filter were chosen based on the excitation and emission spectra of the materials. A 405/20 nm bandpass excitation filter, a dichroic mirror with $425 \mathrm{~nm}$ cut-on wavelength, a 460/50 nm bandpass emission filter were used based on the spectra of Lysotracker blue DMD-22 dye. Images were taken under $100 \times \mathrm{O}$ objective and processed with ImageJ software. The Pearson's correlation coefficient was calculated using the JACoP tool in ImageJ. ${ }^{4}$

\section{Cellular Imaging}

Cells were seeded on gelatin-coated cover slips inside a 12 -well plate $\left(50,000\right.$ cells $\mathrm{mL}^{-1} ; 1 \mathrm{~mL}$ per well) and incubated at $37{ }^{\circ} \mathrm{C}$ in $5 \% \mathrm{CO}_{2}$ overnight to allow for attachment. Then, cells were incubated with polymer dot solutions $\left(25 \mu \mathrm{g} \mathrm{mL} \mathrm{m}^{-1}\right)$ for 30 minutes at $37{ }^{\circ} \mathrm{C}$ in $5 \% \mathrm{CO}_{2}$. All growth medium was subsequently removed, and the cells were washed $3 \mathrm{x}$ with PBS. They were then fixed with $4 \% \mathrm{w} / \mathrm{v}$ paraformaldehyde in PBS at room temperature for 15 minutes, followed by 3 washings with PBS to remove excess paraformaldehyde. The coverslips were then transferred onto microscope slides for imaging. Control samples were subjected to the same washing procedures as test samples.

A $350 / 50 \mathrm{~nm}$ bandpass excitation filter, a dichroic mirror with $470 \mathrm{~nm}$ transmission cut-on wavelength, a $550 \mathrm{~nm}$ longpass emission filter were chosen based on the excitation and emission spectra of the materials. Images were taken under $20 \times$ and $60 \times$ objective and processed with ImageJ software. Control and test samples were collected with the same microscope settings. SBR and SNR were calculated according to equations 2 and 3 , where $\mathrm{I}=$ intensity, $\mathrm{bg}=$ background, and $\sigma=$ standard deviation.

$$
\begin{aligned}
& S B R=\frac{I_{c e l l}-I_{b g}}{I_{b g}} \\
& S N R=\frac{I_{c e l l}-I_{b g}}{\sigma\left(I_{b g}\right)}
\end{aligned}
$$

\section{Time-gated Measurements}

Time-gated measurements were made with an Infinite M1000 Pro plate reader (Tecan). The first set of time-gated emission measurements were made with fluorescein $(\sim 1.17 \mu \mathrm{M}$ in Borate buffer $)$ and Pdots $(\sim 1$ $\mathrm{mg} / \mathrm{mL}$ in water) in Borate buffer $(50 \mathrm{mM}, \mathrm{pH} 8.5)$, either individually or as a mixture $(40 \mu \mathrm{L}$ and $40 \mu \mathrm{L}$, respectively). Prompt/time-gated emission measurements had delay times of $0 \mu \mathrm{s} / 50 \mu \mathrm{s}$ after flash excitation and integration times of $500 \mu \mathrm{s} / 500 \mu \mathrm{s}$. In both cases, the excitation wavelength was $400 \pm 10$ nm.

The second set of time-gated emission measurements were made with Pdots ( $40 \mu \mathrm{L}, \sim 0.33 \mathrm{mg} / \mathrm{mL}$ in HEPES buffer $(50 \mathrm{mM}, \mathrm{pH}=7.1))$ mixed with bovine serum $(40 \mu \mathrm{L})$. Prompt/time-gated emission 
measurements had delay times of $0 \mu \mathrm{s} / 50 \mu \mathrm{s}$ after flash excitation and integration times of $500 \mu \mathrm{s} / 500 \mu \mathrm{s}$. In both cases, the excitation wavelength was $400 \pm 20 \mathrm{~nm}$.

\section{Synthetic Procedures}

Scheme 1. Synthesis of DMAcN and DPAcN monomers.<smiles>O=C1c2cccc3c(Br)ccc(c23)C(=O)N1CCCOC1CCCCO1</smiles>

NAI-THP
['BuPH] $\left[\mathrm{BF}_{4}\right], \mathrm{Pd}(\mathrm{OAc})_{2}$

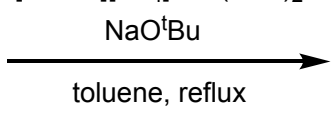

oluene, reflux<smiles>[R]C1([R])c2ccccc2N(c2ccc3c4c(cccc24)C(=O)N(CCCOC2CCCCO2)C3=O)c2ccccc21</smiles>

1: $\mathrm{R}=\mathrm{CH}_{3}$

2: $\mathrm{R}=\mathrm{Ph}$

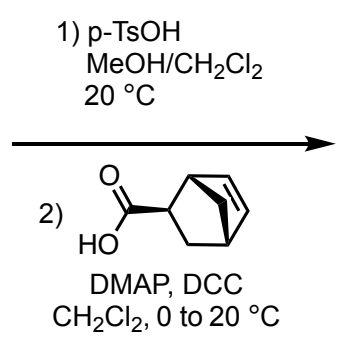

$\mathrm{CH}_{2} \mathrm{Cl}_{2}, 0$ to $20^{\circ} \mathrm{C}$

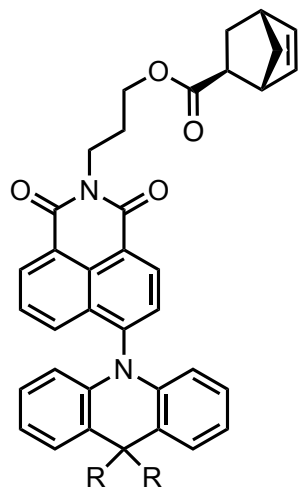

DMAcN: $\mathrm{R}=\mathrm{CH}_{3}, 57 \%$

DPACN: $\mathrm{R}=\mathrm{Ph}, \quad 83 \%$

Scheme 2. Synthesis of mCPN monomer.<smiles>OCc1cc(-n2c3ccccc3c3ccccc32)cc(-n2c3ccccc3c3ccccc32)c1</smiles><smiles>CO[Pb]([O-])(OC)O[Na]</smiles><smiles>O=C(OCc1cc(-n2c3ccccc3c3ccccc32)cc(-n2c3ccccc3c3ccccc32)c1)C1CC2C=CC1C2</smiles> 
Scheme 3. Synthesis of BGN monomer.

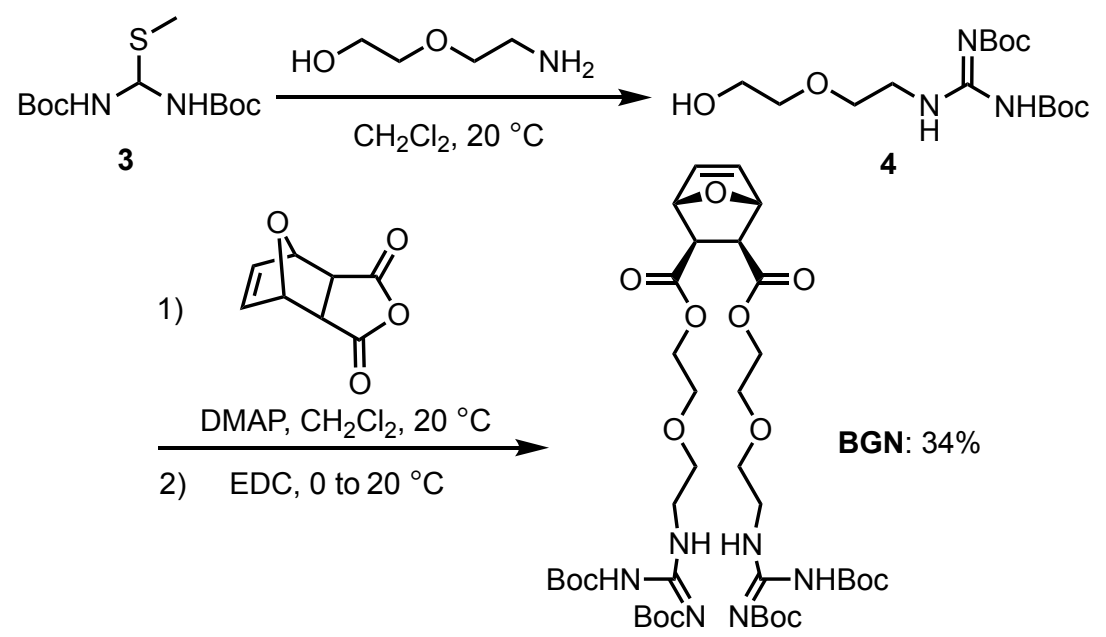

2<smiles>O=C1c2cccc3c(N4c5ccccc5C(c5ccccc5)(c5ccccc5)c5ccccc54)ccc(c23)C(=O)N1CCCOC1CCCCO1</smiles>

Synthesized from a modified literature procedure. ${ }^{1}$ NAI-THP $(0.778 \mathrm{~g}, 1.85 \mathrm{mmol}, 1$ equiv. $)$, 9,9-diphenyl9,10-dihydroacridine (740 mg, $2.22 \mathrm{mmol}, 1.2$ equiv.), [ $\left.{ }^{\mathrm{t}} \mathrm{BuPH}\right]\left[\mathrm{BF}_{4}\right]$ (64.4 mg, $0.22 \mathrm{mmol}, 0.12$ equiv.), $\mathrm{Pd}(\mathrm{OAc})_{2}\left(21 \mathrm{mg}, 0.09 \mathrm{mmol}, 0.05\right.$ equiv.) and $\mathrm{NaO}^{\mathrm{t}} \mathrm{Bu}(0.44 \mathrm{~g}, 4.63 \mathrm{mmol}, 2.5$ equiv.) were combined in a flame-dried 3-neck flask equipped with a stir bar and condenser. The flask with reagents was vacuum $/ \mathrm{N}_{2}$ cycled $(4 \mathrm{x})$. Dry, degassed toluene $(50 \mathrm{~mL})$ was added and the reaction mixture was heated to reflux overnight. After 16 hours, the reaction mixture was cooled, the toluene removed, and the resulting solid was dissolved in $\mathrm{CH}_{2} \mathrm{Cl}_{2}$. The organic layer was washed with $\mathrm{H}_{2} \mathrm{O}(3 \mathrm{x})$ and brine $(1 \mathrm{x})$. The organic layer was dried over $\mathrm{MgSO}_{4}$, and the solvent was removed in vacuo. Purified on silica using a gradient from $0 \%$ to $5 \%$ EtOAc in $\mathrm{CH}_{2} \mathrm{Cl}_{2}$. Product is a yellow crystalline solid $(857 \mathrm{mg}, 55 \%)$. ${ }^{\mathbf{1}} \mathbf{H} \mathbf{~ N M R}(400 \mathbf{~ M H z}, \mathbf{C D C l})$

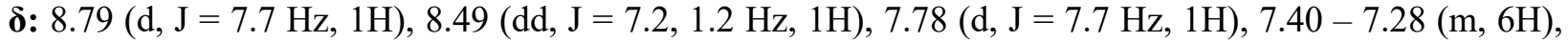
$7.23-7.12(\mathrm{~m}, 3 \mathrm{H}), 7.08-6.88(\mathrm{~m}, 9 \mathrm{H}), 6.35-6.24(\mathrm{~m}, 2 \mathrm{H}), 4.61(\mathrm{t}, \mathrm{J}=3.3 \mathrm{~Hz}, 1 \mathrm{H}), 4.46-4.20(\mathrm{~m}, 2 \mathrm{H})$, $3.98-3.78(\mathrm{~m}, 2 \mathrm{H}), 3.67-3.41(\mathrm{~m}, 2 \mathrm{H}), 2.09(\mathrm{p}, \mathrm{J}=6.8 \mathrm{~Hz}, 2 \mathrm{H}), 1.88-1.60(\mathrm{~m}, 3 \mathrm{H}), 1.55$ - $1.36(\mathrm{~m}$, 3H). ${ }^{13} \mathbf{C}\left\{{ }^{1} \mathbf{H}\right\}$ NMR (101 MHz, $\left.\mathbf{C D C l}_{3}\right) \boldsymbol{\delta}: 164.2,163.8,146.6,146.0,142.9,141.8,132.0,131.6,131.2$, 131.2 , 130.6, 130.5, 130.3, 130.2, 129.8, 128.2, 127.9, 127.9, 127.3, 126.9, 126.7, 123.3, 123.0, 121.1, 113.8, 98.8, 65.7, 62.2, 57.1, 38.4, 30.7, 28.4, 25.6, $19.5 \mathrm{ppm}$. HRMS (FD/TOF) $\mathbf{m} / \mathbf{z}[\mathbf{M}]^{+}$: For $\left[\mathrm{C}_{45} \mathrm{H}_{38} \mathrm{~N}_{2} \mathrm{O}_{4}\right]{ }^{+}$calculated 670.28316; found 670.28467; difference $2.26 \mathrm{ppm}$. 


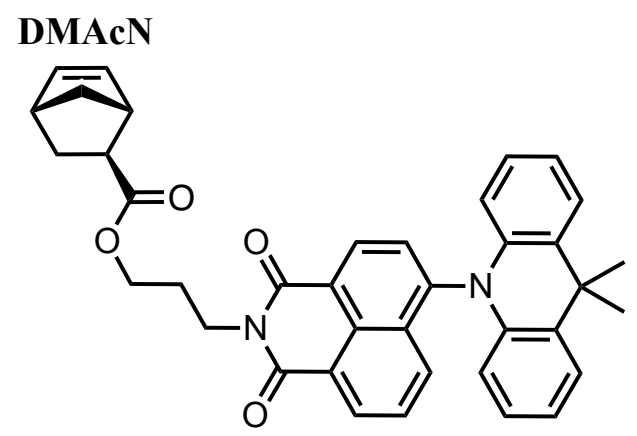

1 (355 mg, $0.65 \mathrm{mmol}, 1$ equiv.) and $p-\mathrm{TsOH} \cdot \mathrm{H}_{2} \mathrm{O}(24.7 \mathrm{mg}, 0.13 \mathrm{mmol}, 0.2$ eq.) were dissolved in a 1:2 mixture of $\mathrm{CH}_{2} \mathrm{Cl}_{2}: \mathrm{MeOH}(10 \mathrm{~mL})$, and the reaction was allowed to proceed at room temperature under air. When the reaction was complete by TLC ( $2 \mathrm{hrs})$, the solvent was removed in vacuo, the crude residue was dissolved in $\mathrm{CH}_{2} \mathrm{Cl}_{2}$ and washed with saturated $\mathrm{NaHCO}_{3}(\mathrm{aq})(3 \mathrm{x})$. The organic layer was dried over $\mathrm{MgSO}_{4}$ and the solvent was removed in vacuo to afford the crude product, which was used without further purification. To the crude alcohol, exo-5-norbornenecarboxylic acid (135 mg, $0.97 \mathrm{mmol}, 1.5 \mathrm{equiv}$.), and DMAP ( $5 \mathrm{mg}, 0.042 \mathrm{mmol}, 0.065$ equiv.) were combined in a three-neck round-bottom flask equipped with a stir bar and dissolved in dry $\mathrm{CH}_{2} \mathrm{Cl}_{2}(10 \mathrm{~mL})$. The reaction mixture was cooled to $0{ }^{\circ} \mathrm{C}$. $\mathrm{DCC}(161 \mathrm{mg}$, $0.78 \mathrm{mmol}, 1.2$ equiv.) was added at $0{ }^{\circ} \mathrm{C}$ and the reaction was allowed to warm to room temperature. The reaction was stirred overnight, before being filtered and washed with $\mathrm{CH}_{2} \mathrm{Cl}_{2}$. The filtrate was evaporated and purified over silica with a gradient of $100 \% \mathrm{CH}_{2} \mathrm{Cl}_{2}$ to $5 \%$ EtOAc in $\mathrm{CH}_{2} \mathrm{Cl}_{2}$. The product was then recrystallized from $\mathrm{CH}_{2} \mathrm{Cl}_{2}$ /hexanes to obtain pure product as an orange-red crystalline solid $(215 \mathrm{mg}, 57 \%)$. ${ }^{1} \mathbf{H}$ NMR (400 MHz, $\left.\mathbf{C D C l}_{3}\right)$ \&: $8.82(\mathrm{~d}, J=7.7 \mathrm{~Hz}, 1 \mathrm{H}), 8.64(\mathrm{dd}, J=7.3,1.2 \mathrm{~Hz}, 1 \mathrm{H}), 8.04$ (dd, $J=8.5$, $1.2 \mathrm{~Hz}, 1 \mathrm{H}), 7.80$ (d, $J=7.7 \mathrm{~Hz}, 1 \mathrm{H}), 7.64$ (dd, $J=8.5,7.2 \mathrm{~Hz}, 1 \mathrm{H}), 7.54$ (dd, $J=7.8,1.5 \mathrm{~Hz}, 2 \mathrm{H}), 6.95$ (td, $J=7.5,1.3 \mathrm{~Hz}, 2 \mathrm{H}), 6.86(\mathrm{ddd}, J=8.7,7.3,1.6 \mathrm{~Hz}, 2 \mathrm{H}), 6.11(\mathrm{dd}, J=5.7,3.0 \mathrm{~Hz}, 1 \mathrm{H}), 6.02(\mathrm{dd}, J=$ $5.7,3.1 \mathrm{~Hz}, 1 \mathrm{H}), 5.93(\mathrm{dd}, J=8.2,1.3 \mathrm{~Hz}, 2 \mathrm{H}), 4.39(\mathrm{t}, J=7.0 \mathrm{~Hz}, 2 \mathrm{H}), 4.32-4.20(\mathrm{~m}, 2 \mathrm{H}), 3.04(\mathrm{dd}, J=$ $3.2,1.6 \mathrm{~Hz}, 1 \mathrm{H}), 2.88(\mathrm{~s}, 1 \mathrm{H}), 2.18(\mathrm{~m}, 4 \mathrm{H}), 1.93(\mathrm{dt}, J=11.6,4.0 \mathrm{~Hz}, 1 \mathrm{H}), 1.81(\mathrm{~d}, J=33.3 \mathrm{~Hz}, 6 \mathrm{H}), 1.51$ (s, 1H), $1.38-1.29$ (m, 2H) ppm. ${ }^{13} \mathbf{C}\left\{{ }^{1} \mathbf{H}\right\}$ NMR (101 $\left.\mathbf{M H z}, \mathbf{C D C l}_{3}\right) \boldsymbol{\delta}:$ 176.4, 164.1, 163.8, 144.5, 140.2, $138.16,135.9,132.8,132.2,130.9,130.4,130.1,128.2,126.9,126.1,123.8,123.0,121.4,114.2,62.7,46.7$, 46.6, 43.3, 41.8, 38.0, 36.2, 32.9, 32.2, 30.5, $27.6 \mathrm{ppm}$. HRMS (ESI/TOF) $\boldsymbol{m} / \boldsymbol{z}[\mathbf{M}]{ }^{+}$: For $\left[\mathrm{C}_{38} \mathrm{H}_{34} \mathrm{~N}_{2} \mathrm{O}_{4}\right] \cdot^{+}$ calculated 582.2519; found 582.2521; difference $0.40 \mathrm{ppm}$.

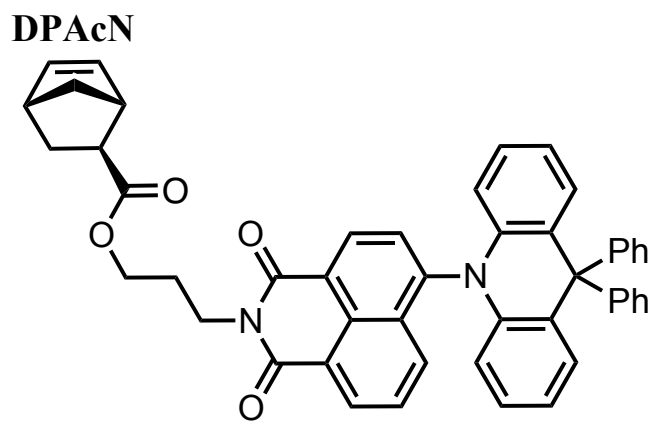

2 (402 mg, $0.60 \mathrm{mmol}, 1$ equiv.) and $p-\mathrm{TsOH} \bullet \mathrm{H}_{2} \mathrm{O}(23 \mathrm{mg}, 0.12 \mathrm{mmol}, 0.2$ eq.) were dissolved in a 1:2 mixture of $\mathrm{CH}_{2} \mathrm{Cl}_{2}: \mathrm{MeOH}(10 \mathrm{~mL})$, and the reaction was allowed to proceed at room temperature under air. When the reaction was complete by TLC ( $2 \mathrm{hrs})$, the solvent was removed in vacuo, the crude residue was dissolved in $\mathrm{CH}_{2} \mathrm{Cl}_{2}$ and washed with saturated $\mathrm{NaHCO}_{3}(\mathrm{aq})(3 \mathrm{x})$. The organic layer was dried over $\mathrm{MgSO}_{4}$ and the solvent was removed in vacuo to afford the crude product, which was used without further purification. To the crude alcohol, exo-5-norbornenecarboxylic acid (124 mg, $0.89 \mathrm{mmol}, 1.5 \mathrm{equiv}$.), and DMAP (5 mg, $0.039 \mathrm{mmol}, 0.065$ equiv.) were combined in a three-neck round-bottom flask equipped with a stir bar and dissolved in dry $\mathrm{CH}_{2} \mathrm{Cl}_{2}(10 \mathrm{~mL})$. The reaction mixture was cooled to $0{ }^{\circ} \mathrm{C}$. $\mathrm{DCC}(148 \mathrm{mg}$, $0.72 \mathrm{mmol}, 1.2$ equiv.) was added at $0{ }^{\circ} \mathrm{C}$ and the reaction was allowed to warm to room temperature. The 
reaction was stirred overnight, before being filtered and washed with $\mathrm{CH}_{2} \mathrm{Cl}_{2}$. The filtrate was evaporated and purified over silica with $100 \% \mathrm{CH}_{2} \mathrm{Cl}_{2}$. The product was then recrystallized from $\mathrm{CH}_{2} \mathrm{Cl}_{2}$ /hexanes to obtain pure product as an orange crystalline solid (349 mg, 83\%). ${ }^{1} \mathbf{H}$ NMR (400 $\left.\mathbf{~ M H z}, \mathbf{C D C l}_{3}\right) \boldsymbol{\delta}: 8.79$ (d, $J=7.7 \mathrm{~Hz}, 1 \mathrm{H}), 8.49(\mathrm{~d}, J=7.2 \mathrm{~Hz}, 1 \mathrm{H}), 7.79(\mathrm{~d}, J=7.7 \mathrm{~Hz}, 1 \mathrm{H}), 7.43-6.87(\mathrm{~m}, 18 \mathrm{H}), 6.28(\mathrm{~d}, J=8.1$ $\mathrm{Hz}, 2 \mathrm{H}), 6.10(\mathrm{dd}, J=5.7,3.0 \mathrm{~Hz}, 1 \mathrm{H}), 6.01(\mathrm{dd}, J=5.7,3.0 \mathrm{~Hz}, 1 \mathrm{H}), 4.35(\mathrm{t}, J=7.0 \mathrm{~Hz}, 2 \mathrm{H}), 4.25(\mathrm{t}, J=$ $6.2 \mathrm{~Hz}, 2 \mathrm{H}), 3.04(\mathrm{~s}, 1 \mathrm{H}), 2.88(\mathrm{~s}, 1 \mathrm{H}), 2.16(\mathrm{~m}, 2 \mathrm{H}), 1.92(\mathrm{~m}, 1 \mathrm{H}), 1.61(\mathrm{~s}, 1 \mathrm{H}), 1.52(\mathrm{~d}, J=8.5 \mathrm{~Hz}, 1 \mathrm{H})$, 1.39 - 1.23 (m, 2H) ppm. ${ }^{13} \mathbf{C}\left\{{ }^{1} \mathbf{H}\right\}$ NMR (101 MHz, $\left.\mathbf{C D C l}_{3}\right) \boldsymbol{\delta}:$ 176.3, 164.1, 163.7, 146.6, 146.0, 143.1, $141.8,138.1,135.9,132.1,131.7,131.2,130.7,130.5,130.3,130.2,129.9,128.2,127.9,127.3,126.9$, 126.7, 123.1, 122.8, 121.1, 113.8, 62.6, 57.1, 46.7, 46.5, 43.3, 41.8, 37.9, 30.4, 27.6 ppm. HRMS (ESI/TOF) $\boldsymbol{m} / z[\mathbf{M}]^{+}$: For $\left[\mathrm{C}_{48} \mathrm{H}_{38} \mathrm{~N}_{2} \mathrm{O}_{4}\right]{ }^{+}$calculated 706.2832; found 706.2833; difference $0.24 \mathrm{ppm}$.

\section{mCPN}<smiles>O=C(OCc1cc(-n2c3ccccc3c3ccccc32)cc(-n2c3ccccc3c3ccccc32)c1)C1CC2C=CC1C2</smiles>

mCP-OH (3.34 g, 7.62 mmol, 1.0 equiv.), exo-5-norbornenecarboxylic acid (1.59 g, $11.42 \mathrm{mmol}, 1.5$ equiv.), and DMAP (60.5 mg, $0.50 \mathrm{mmol}, 0.065$ equiv.) were combined in a three-neck round-bottom flask equipped with a stir bar and dissolved in dry $\mathrm{CH}_{2} \mathrm{Cl}_{2}(100 \mathrm{~mL})$. The reaction mixture was cooled to $0{ }^{\circ} \mathrm{C}$. DCC $\left(1.89 \mathrm{~g}, 9.14 \mathrm{mmol}, 1.2\right.$ equiv.) was added at $0{ }^{\circ} \mathrm{C}$ and the reaction was allowed to warm to room temperature. The reaction was stirred overnight, before being filtered and washed with $\mathrm{CH}_{2} \mathrm{Cl}_{2}$. The filtrate was evaporated and purified over silica with 1:1 hexanes/ $\mathrm{CH}_{2} \mathrm{Cl}_{2}$. The product was then recrystallized from $\mathrm{CH}_{2} \mathrm{Cl}_{2}$ /hexanes to obtain pure product as a white fluffy solid $\left.(3.39 \mathrm{~g}, 80 \%) .{ }^{\mathbf{1}} \mathbf{H} \mathbf{~ N M R ~ ( 4 0 0 ~} \mathbf{M H z}, \mathbf{C D C l} \mathbf{C D}_{3}\right)$ $\delta: 8.16(\mathrm{~d}, J=7.7 \mathrm{~Hz}, 4 \mathrm{H}), 7.79(\mathrm{t}, J=2.0 \mathrm{~Hz}, 1 \mathrm{H}), 7.70(\mathrm{~d}, J=1.9 \mathrm{~Hz}, 2 \mathrm{H}), 7.55(\mathrm{~d}, J=8.2 \mathrm{~Hz}, 4 \mathrm{H}), 7.50$ $-7.40(\mathrm{~m}, 4 \mathrm{H}), 7.37-7.28(\mathrm{~m}, 4 \mathrm{H}), 6.21-6.06(\mathrm{~m}, 2 \mathrm{H}), 5.37(\mathrm{~s}, 2 \mathrm{H}), 3.12(\mathrm{~d}, J=3.0 \mathrm{~Hz}, 1 \mathrm{H}), 2.95(\mathrm{~s}$, $1 \mathrm{H}), 2.36$ (ddd, $J=9.0,4.5,1.5 \mathrm{~Hz}, 1 \mathrm{H}), 2.00(\mathrm{dt}, J=11.9,4.0 \mathrm{~Hz}, 1 \mathrm{H}), 1.60-1.56(\mathrm{~m}, 1 \mathrm{H}), 1.48-1.37$ (m, 2H) ppm. ${ }^{13} \mathbf{C}$ NMR (101 MHz, $\left.\mathbf{C D C l}_{3}\right) \delta: 176.1,140.6,140.4,139.7,138.3,135.8,126.3,124.8$, 124.6, 123.8, 120.6, 120.6, 109.8, 65.3, 46.8, 46.6, 43.3, 41.8, $30.7 \mathrm{ppm}$. HRMS (ESI/TOF) $\mathbf{m} / \boldsymbol{z}$ [M] ${ }^{+}$: For $\left.\left[\mathrm{C}_{39} \mathrm{H}_{30} \mathrm{~N}_{2} \mathrm{O}_{2}\right]\right]^{+}$calculated 558.2307; found 558.2306; difference $-0.29 \mathrm{ppm}$.

Bisguanidinylnorbornene (BGN)

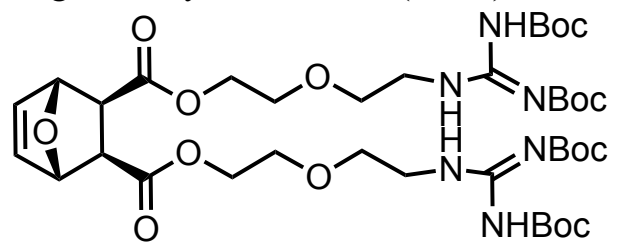

4 (6.4 g, 18.4 mmol, 1.9 equiv.), exo-3a,4,7,7a-tetrahydro-4,7-epoxyisobenzofuran-1,3-dione (1.61 g, 9.7 mmol, 1.0 equiv.), and DMAP (118 mg, $0.97 \mathrm{mmol}, 0.1$ equiv.) were combined in dry $\mathrm{CH}_{2} \mathrm{Cl}_{2}(30 \mathrm{~mL})$ in a Schlenk flask equipped with a stir bar. The reaction was stirred at room temperature overnight. The reaction was then cooled to $0{ }^{\circ} \mathrm{C}$, and $\mathrm{EDC} \cdot \mathrm{HCl}(1.86 \mathrm{~g}, 9.7 \mathrm{mmol}, 1.0$ equiv.) was added in 1 portion, after which the reaction was stirred at room temperature overnight. The reaction was diluted with $\mathrm{CH}_{2} \mathrm{Cl}_{2}$, washed with $\mathrm{KHSO}_{4}\left(10 \%\right.$ aq.) and sat. $\mathrm{NaHCO}_{3}$ (aq.), dried over $\mathrm{MgSO}_{4}$, and concentrated in vacuo. The product was purified with an alumina plug $\left(\mathrm{CH}_{2} \mathrm{Cl}_{2}\right)$ and silica (gradient of 9:1 hexanes/EtOAc to 1:1 hexanes/EtOAc) to give a white solid (2.80 g, 34\%). ${ }^{1} \mathbf{H}$ NMR (400 MHz, $\left.\mathbf{C D C l}_{3}\right) \boldsymbol{\delta}: 11.48$ (s, 2H), 8.59 
(s, 2H), $6.44(\mathrm{~s}, 2 \mathrm{H}), 5.28(\mathrm{~s}, 2 \mathrm{H}), 4.43-4.12(\mathrm{~m}, 4 \mathrm{H}), 3.65(\mathrm{dt}, \mathrm{J}=20.4,4.3 \mathrm{~Hz}, 12 \mathrm{H}), 2.86(\mathrm{~s}, 2 \mathrm{H}), 1.49$ $(\mathrm{d}, \mathrm{J}=4.6 \mathrm{~Hz}, 36 \mathrm{H}) \mathrm{ppm} .{ }^{13} \mathbf{C}\left\{{ }^{1} \mathbf{H}\right\} \mathbf{N M R}\left(\mathbf{1 0 1} \mathbf{M H z}, \mathbf{C D C l}_{\mathbf{3}}\right) \boldsymbol{\delta}: \mathbf{1 7 1 . 3}, \mathbf{1 6 3 . 4}, \mathbf{1 5 6 . 1}, 152.8,136.5,82.8$, 80.5, 79.1, 69.1, 68.5, 64.1, 46.7, 40.4, 28.2, $28.0 \mathrm{ppm}$. HRMS (FD/TOF) $\mathbf{m} / \mathbf{z}\left[\mathbf{M}+\mathbf{H}^{+}\right.$: For $\left[\mathrm{C}_{38} \mathrm{H}_{63} \mathrm{~N}_{6} \mathrm{O}_{15}\right]^{+}$calculated 843.43514; found 843.43487; difference $-0.32 \mathrm{ppm}$.

\section{Preparation of $\mathbf{~ m C P N}_{\mathbf{9 0}}-\mathbf{c o}-\mathbf{D M A C N}_{\mathbf{1 0}}$}

mCPN (207.9 mg, $0.37 \mathrm{mmol}, 90$ equiv.) and DMAcN (24.9 mg, $0.04 \mathrm{mmol}, 10$ equiv.) were added to a 4 $\mathrm{mL}$ vial (equipped with a teflon stir bar and cap), dissolved in $\mathrm{CH}_{2} \mathrm{Cl}_{2}\left(1.3 \mathrm{~mL}\right.$ ), and cooled to $-20{ }^{\circ} \mathrm{C}$ under $\mathrm{N}_{2}$ atmosphere. Grubbs G3 (300 $\mu \mathrm{L}, 1 \mathrm{mg} \mathrm{mL}^{-1}$ in $\mathrm{CH}_{2} \mathrm{Cl}_{2}, 0.004 \mathrm{mmol}, 1$ equiv.) was then added rapidly in one portion. Once the polymer had reached $99 \%$ conversion by ${ }^{1} \mathrm{H}$ NMR (approximately $24 \mathrm{~h}$ ) ethyl vinyl ether $(100 \mu \mathrm{L})$ was added and the reaction was stirred for $15 \mathrm{~min}$. The reaction was warmed to room temperature $\left(\sim 20^{\circ} \mathrm{C}\right)$ and the crude polymer was precipitated into $50 \mathrm{~mL}$ of methanol. The precipitated product was isolated by vacuum filtration. The crude solid was purified by preparatory scale SEC using THF, concentrated in vacuo, and reprecipitated in methanol from minimal $\mathrm{CH}_{2} \mathrm{Cl}_{2}$. The pure polymer was isolated by vacuum filtration to obtain an orange powder $(104.4 \mathrm{mg}, 45 \%)$. DMAcN doping \%(NMR) $=10$ $\mathrm{mol} \% ; M_{n \text { (target) }}=56,900 ; M_{n(\mathrm{GPC})}=54,900 ; \mathrm{Ð}_{(\mathrm{SEC})}=1.08$.

\section{Preparation of $\mathbf{m C P N}_{\mathbf{9 1}}-\mathrm{Co}_{\mathbf{0}}-\mathrm{DPAcN} \mathbf{9}$}

mCPN (209.7 mg, $0.37 \mathrm{mmol}, 91$ eq.) and DPAcN (25.2 mg, $0.04 \mathrm{mmol}, 9$ eq.) were added to a $4 \mathrm{~mL}$ vial (equipped with a teflon stir bar and cap), dissolved in $\mathrm{CH}_{2} \mathrm{Cl}_{2}(1.3 \mathrm{~mL})$, and cooled to $-20{ }^{\circ} \mathrm{C}$ under $\mathrm{N}_{2}$ atmosphere. Grubbs $\mathrm{G} 3\left(300 \mu \mathrm{L}, 1 \mathrm{mg} \mathrm{mL}^{-1}\right.$ in $\mathrm{CH}_{2} \mathrm{Cl}_{2}, 0.004$ mmol, 1 equiv.) was then added rapidly in one portion. Once the polymer had reached $99 \%$ conversion by ${ }^{1} \mathrm{H}$ NMR (approximately $24 \mathrm{~h}$ ) ethyl vinyl ether $(100 \mu \mathrm{L})$ was added and the reaction was stirred for $15 \mathrm{~min}$. The reaction was warmed to room temperature $\left(\sim 20^{\circ} \mathrm{C}\right)$ and the crude polymer was precipitated into $50 \mathrm{~mL}$ of methanol. The precipitated product was isolated by vacuum filtration. The crude solid was purified by preparatory scale SEC using THF, concentrated in vacuo, and reprecipitated in methanol from minimal $\mathrm{CH}_{2} \mathrm{Cl}_{2}$. The pure polymer was isolated by vacuum filtration to obtain an orange powder $(98.6 \mathrm{mg}, 42 \%)$. DPAcN doping $\%(\mathrm{NMR})=9 \mathrm{~mol} \%$; $M_{n \text { (target) }}=57,300 ; M_{n(\mathrm{GPC})}=63,700 ; \mathrm{Ð}_{(\mathrm{SEC})}=1.08$.

\section{General Procedure A: Preparation $\mathbf{B G N}_{\mathbf{1 0}}-\mathbf{b}-\mathbf{-} \mathbf{M}_{\mathbf{2 0}}$}

BGN (50.0 mg, $0.06 \mathrm{mmol}, 10$ eq.) was added to a $4 \mathrm{~mL}$ vial (equipped with a teflon stir bar and cap), dissolved in $\mathrm{CH}_{2} \mathrm{Cl}_{2}(85 \mu \mathrm{L})$. Grubbs $\mathrm{G} 3\left(215 \mu \mathrm{L}, 1 \mathrm{mg} \mathrm{mL}{ }^{-1}\right.$ in $\mathrm{CH}_{2} \mathrm{Cl}_{2}, 0.006 \mathrm{mmol}, 1$ equiv.) was then added rapidly in one portion. After 3 hours, the reaction was cooled to $-20^{\circ} \mathrm{C}$. Separately, $\mathbf{m C P N}(59.3 \mathrm{mg}$, $0.11 \mathrm{mmol}, 17.9$ equiv.) and DMAcN (7.4 $\mathrm{mg}, 0.013 \mathrm{mmol}, 2.1$ equiv.) were brought into the glovebox and dissolved in $\mathrm{CH}_{2} \mathrm{Cl}_{2}(571 \mu \mathrm{L})$. This solution was cooled to $-20{ }^{\circ} \mathrm{C}$, and added in one portion to the polymerization vial. Once this block had reached $99 \%$ conversion by ${ }^{1} \mathrm{H}$ NMR (approximately $24 \mathrm{~h}$ ), ethyl vinyl ether $(100 \mu \mathrm{L})$ was added and the reaction was stirred for $15 \mathrm{~min}$. The reaction was warmed to room temperature $\left(\sim 20^{\circ} \mathrm{C}\right)$ and the crude polymer was precipitated into $50 \mathrm{~mL}$ of methanol. The precipitated product was isolated by vacuum filtration. The crude solid was purified by preparatory-scale SEC using THF, concentrated in vacuo, and then stirred overnight in $1: 1 \mathrm{MeOH} / 0.2 \mathrm{M} \mathrm{HCl}$ (aq.) to remove the protecting groups. The polymer was then purified by dialysis (Spectra/Por molecularporous membrane tubing, $\mathrm{MWCO}=3.5 \mathrm{kD}$ ) in Milli-Q water to remove any small molecules, then collected by lyophilization. The polymer molecular weights and dispersities were characterized before deprotection, as the Bocprotected polymers had better solubility in organic solvents. The molecular weights for the $1^{\text {st }}$ block were calculated from SEC, and the $2^{\text {nd }}$ block were calculated by ${ }^{1} \mathrm{H}$ NMR by using the relative integrations of the peaks at 7.98 and $8.56 \mathrm{ppm}$. Yield: $65.3 \mathrm{mg}, 56 \%$, orange powder. $M_{n \text { (target) }}=11,300 ; M_{n}$ (SEC) $=10,700$; $\mathrm{Ð}_{(\mathrm{SEC})}=1.17$. 


\section{Preparation of $\mathbf{B G N}_{\mathbf{2 0}}-\boldsymbol{b}-\mathrm{M}_{\mathbf{2 0}}$}

Prepared according to General Procedure A, using the following amounts: BGN (50.0 mg, $0.06 \mathrm{mmol}, 20$ equiv.), Grubbs $\mathrm{G} 3$ (108 $\mu \mathrm{L}, 1 \mathrm{mg} \mathrm{mL}{ }^{-1}$ in $\mathrm{CH}_{2} \mathrm{Cl}_{2}, 0.003 \mathrm{mmol}, 1$ equiv.), mCPN (29.7 mg, $0.05 \mathrm{mmol}$, 17.9 equiv.), DMAcN (3.71 mg, $0.006 \mathrm{mmol}, 2.1$ equiv.). Yield: $40.3 \mathrm{mg}, 48 \%$, orange powder. $M_{n \text { (target) }}=$ 11,$300 ; M_{n(\mathrm{SEC})}=12,300 ; \mathrm{Ð}_{(\mathrm{SEC})}=1.26$.

\section{Preparation of $\mathbf{B G N}_{\mathbf{1 0}}-\boldsymbol{b}-\mathbf{P}_{\mathbf{2 0}}$}

Prepared according to General Procedure A, using the following amounts: BGN (50.0 mg, $0.06 \mathrm{mmol}, 10$ equiv.), Grubbs $\mathrm{G} 3\left(215 \mu \mathrm{L}, 1 \mathrm{mg} \mathrm{mL}{ }^{-1}\right.$ in $\mathrm{CH}_{2} \mathrm{Cl}_{2}, 0.006 \mathrm{mmol}, 1$ equiv.), mCPN (59.3 mg, $0.11 \mathrm{mmol}$, 17.9 equiv.), DPAcN (7.4 mg, $0.01 \mathrm{mmol}, 1.8$ equiv.). Yield: $64.0 \mathrm{mg}, 55 \%$, yellow powder. $M_{n}$ (target) $=$ 11,$300 ; M_{n(\mathrm{SEC})}=11,400 ; \mathrm{Ð}_{(\mathrm{SEC})}=1.25$.

\section{Preparation of $\mathbf{B G N _ { 2 0 } - b - P _ { 2 0 }}$}

Prepared according to General Procedure A, using the following amounts: BGN (50.0 mg, $0.06 \mathrm{mmol}, 20$ equiv.), Grubbs G3 (108 $\mu \mathrm{L}, 1 \mathrm{mg} \mathrm{mL}{ }^{-1}$ in $\mathrm{CH}_{2} \mathrm{Cl}_{2}, 0.003 \mathrm{mmol}, 1$ equiv.), mCPN (29.7 mg, $0.053 \mathrm{mmol}$, 17.9 equiv.), DPAcN (3.71 mg, $0.005 \mathrm{mmol}, 1.8$ equiv.). Yield: $38.2 \mathrm{mg}, 46 \%$, yellow powder. $M_{n \text { (target) }}=$ 11,$300 ; M_{n(\mathrm{SEC})}=11,400 ; \mathrm{Ð}_{(\mathrm{SEC})}=1.26$.

\section{Supplementary Tables}

Table S1. Mean cellular fluorescence in B610-ECD-A channel, from flow cytometry.

\begin{tabular}{llllllllll}
\hline & HeLa & \multicolumn{3}{c}{ CHO } & \multicolumn{3}{c}{ HepG2 } \\
\hline Control & 5930 & & & 3900 & & 11050 & \\
\hline Pdot Conc. $(\mu \mathrm{g} / \mathrm{mL})$ & 5 & 10 & 25 & 5 & 10 & 25 & 5 & 10 & 25 \\
\hline BGN $_{10}-\boldsymbol{b}-\mathbf{M}_{\mathbf{2 0}}$ & 9280 & 13200 & 15400 & 5440 & 6630 & 8330 & 28500 & 40640 & 69500 \\
BGN $_{20}-\boldsymbol{b}-\mathbf{M}_{20}$ & 8370 & 9280 & 10130 & 9200 & 10400 & 12400 & 14480 & 18150 & 22170 \\
BGN $_{10}-\boldsymbol{b}-\mathbf{P}_{\mathbf{2 0}}$ & 8880 & 9800 & 11340 & 8600 & 10200 & 11800 & 29200 & 43980 & 66300 \\
BGN $_{20}-\boldsymbol{b}-\mathbf{P}_{\mathbf{2 0}}$ & 8290 & 8640 & 9000 & 9570 & 10470 & 15750 & 16310 & 19630 & 24100 \\
\hline
\end{tabular}




\section{Supplementary Figures}

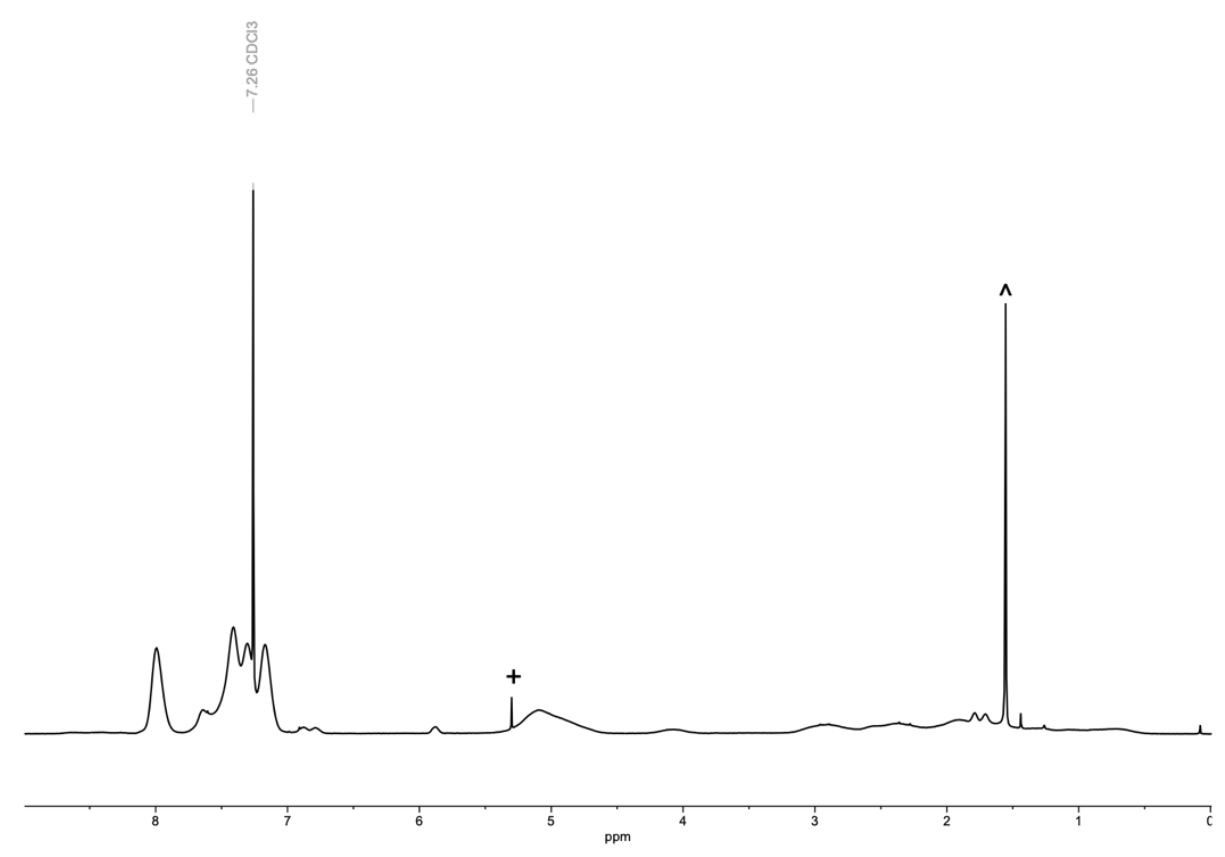

Figure S1. ${ }^{1} \mathrm{H}$ NMR (400 MHz) spectrum of $\mathbf{m C P N}_{\mathbf{9 0}}$-co-DMAcN $\mathbf{c}$ in $\mathrm{CDCl}_{3} .{ }^{\wedge}=\mathrm{H}_{2} \mathrm{O},+=\mathrm{CH}_{2} \mathrm{Cl}_{2}$.
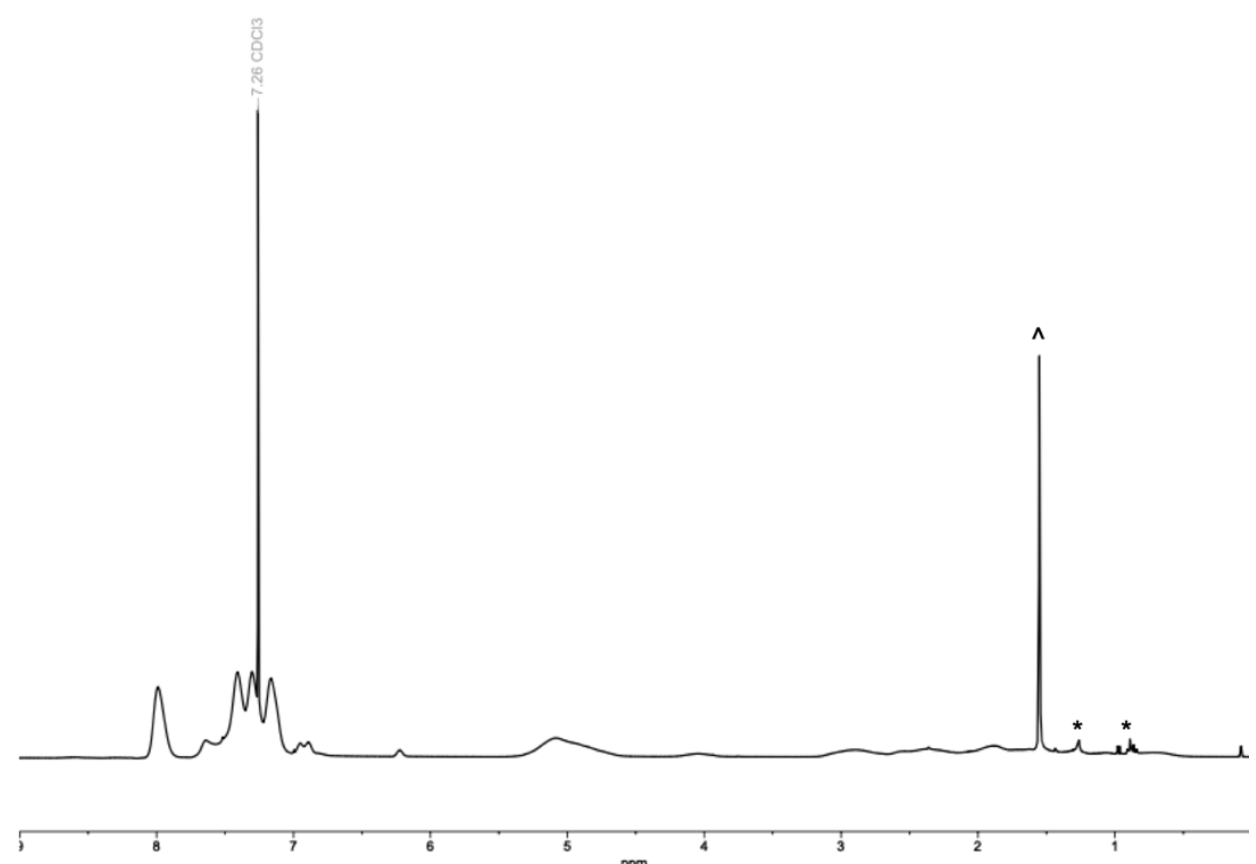

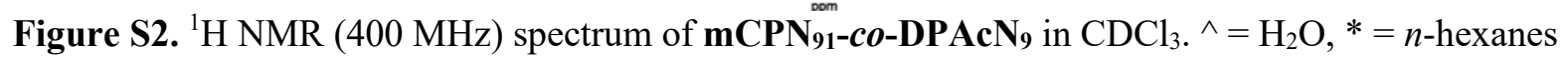



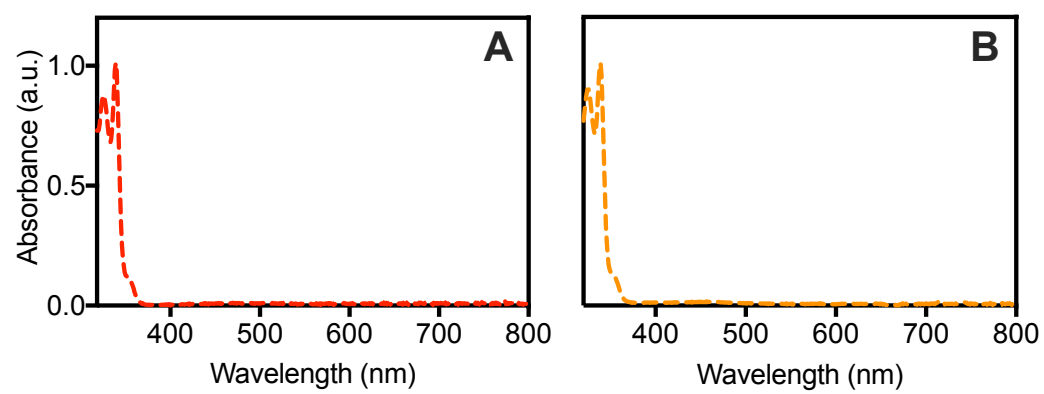

Figure S3. Absorbance spectra of (A) $\mathbf{m C P N}_{90}-c o-\mathbf{D M A c N}_{10}$ and (B) $\mathbf{m C P N}_{91}-c o-D P A c N_{9}$ in toluene at $0.01 \mathrm{mg} \mathrm{mL}^{-1}$.

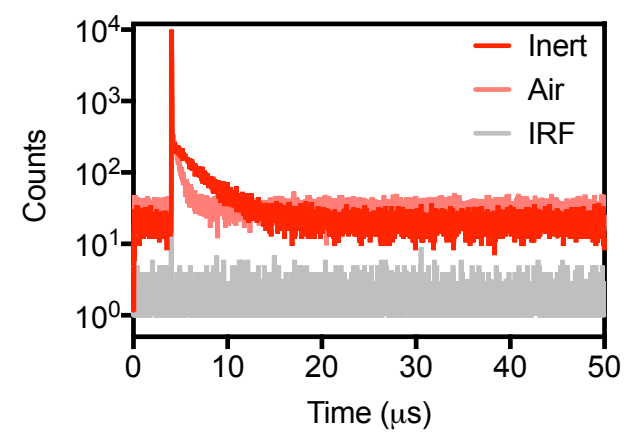

Figure S4. Solution-state photoluminescence lifetimes of $\mathbf{m C P N}_{\mathbf{9 0}}-\mathbf{c o}-\mathbf{D M A c N} \mathbf{N}_{\mathbf{1 0}}$ in toluene at $0.01 \mathrm{mg}$ $\mathrm{mL}^{-1} \cdot \lambda_{\mathrm{ex}}=313 \mathrm{~nm}$.
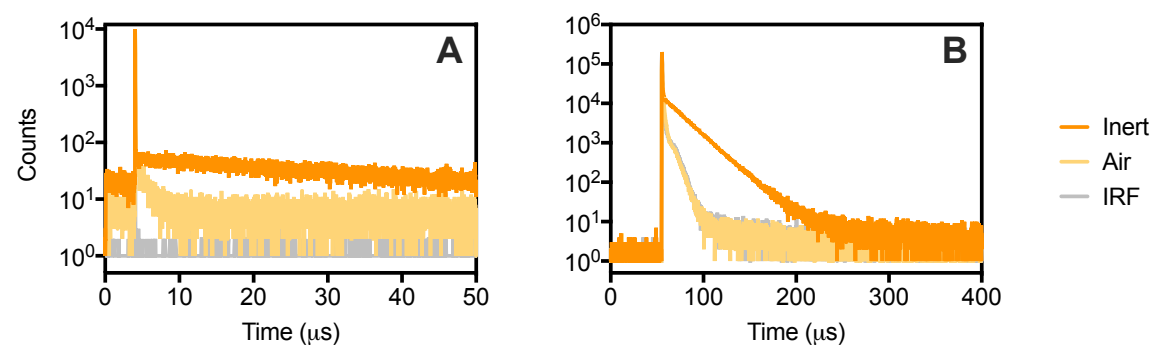

Figure S5. Solution photoluminescence lifetimes of $\mathbf{m C P N}_{\mathbf{9 1}}$-co-DPAcN $\mathbf{c}$ using (A) TCSPC or (B) MCS in toluene at $0.01 \mathrm{mg} \mathrm{mL}^{-1} . \lambda_{\mathrm{ex}}=313 \mathrm{~nm}$. 

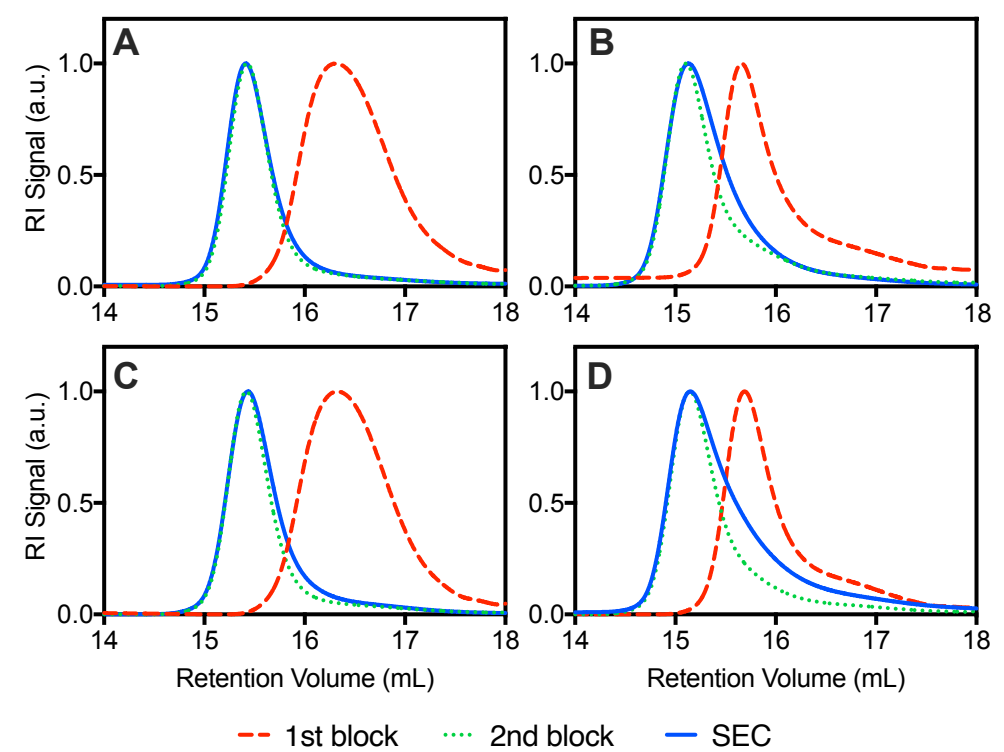

Figure S6. SEC traces of Boc-protected diblock copolymers showing aliquot after $1^{\text {st }}$ block, aliquot after $2^{\text {nd }}$ block, and the purified polymer. (A) $\mathbf{B G N}_{\mathbf{1 0}}-\boldsymbol{b}-\mathbf{M}_{\mathbf{2 0}}$, (B) $\mathbf{B G N}_{\mathbf{2 0}}-\boldsymbol{b}-\mathbf{M}_{\mathbf{2 0}}$, (C) $\mathbf{B} \mathbf{G N}_{\mathbf{1 0}}-\boldsymbol{b}-\mathbf{P}_{\mathbf{2 0}}$, and (D) BGN $_{20}-b-P_{20}$.

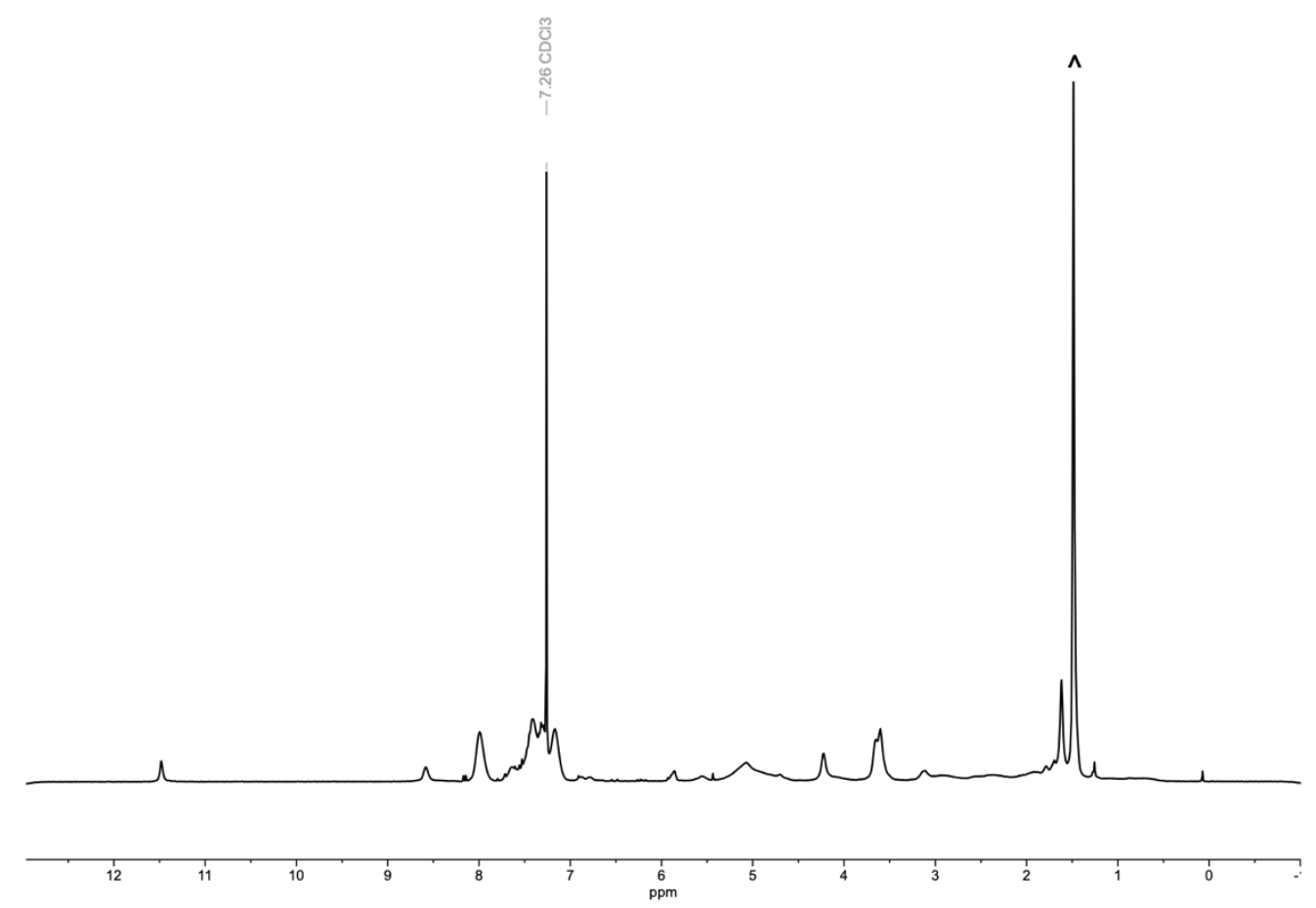

Figure S7. ${ }^{1} \mathrm{H}$ NMR (400 MHz) spectrum of Boc-protected $\mathbf{B G N}_{\mathbf{1 0}}-\boldsymbol{b}-\mathbf{M}_{\mathbf{2 0}}$ in $\mathrm{CDCl}_{3} \cdot{ }^{\wedge}=\mathrm{H}_{2} \mathrm{O}$ 


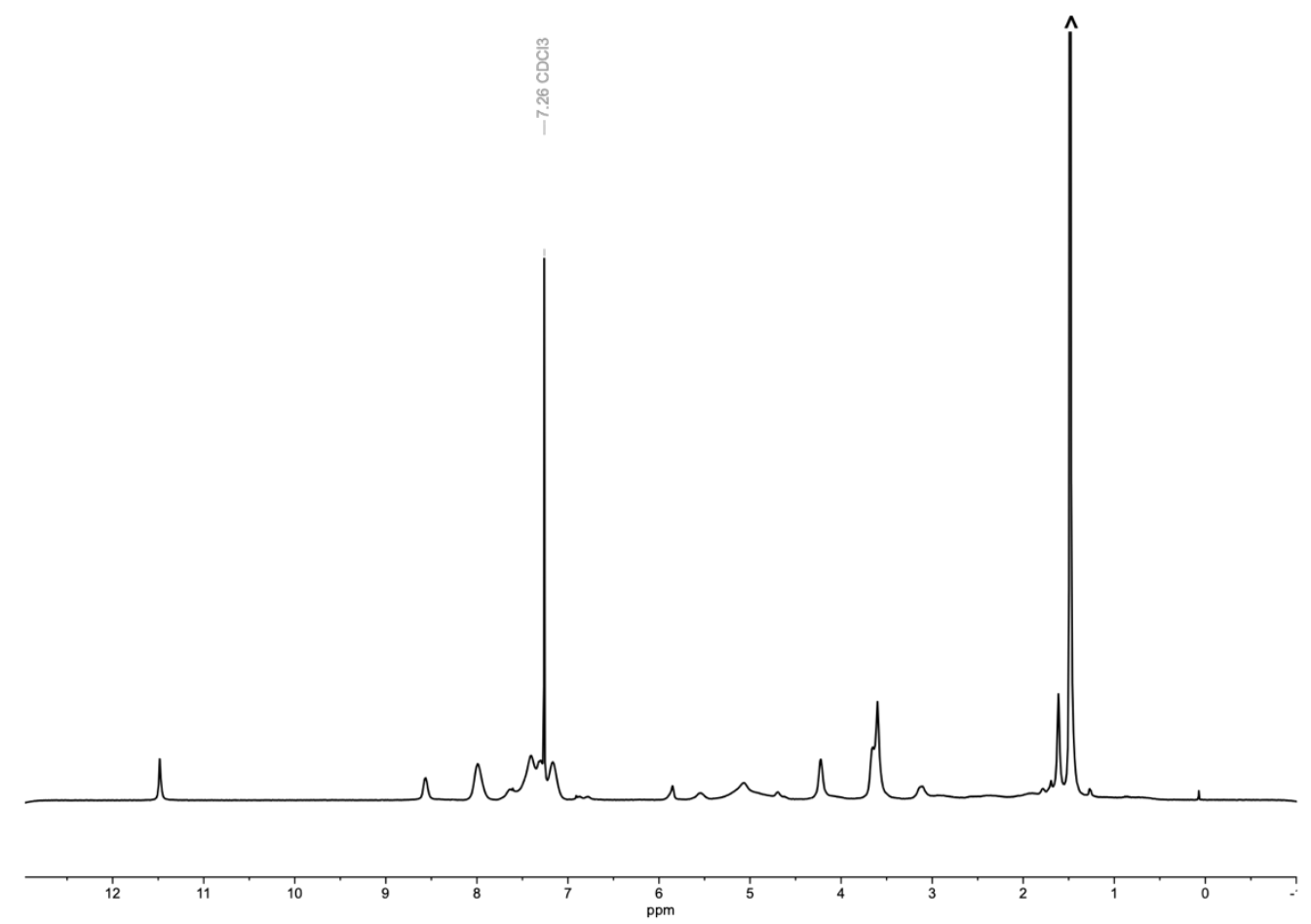

Figure S8. ${ }^{1} \mathrm{H}$ NMR (400 MHz) spectrum of Boc-protected $\mathbf{B G N} \mathbf{N}_{\mathbf{2 0}}-\boldsymbol{b}-\mathbf{M}_{\mathbf{2 0}}$ in $\mathrm{CDCl}_{3} . \wedge{ }^{\wedge}=\mathrm{H}_{2} \mathrm{O}$

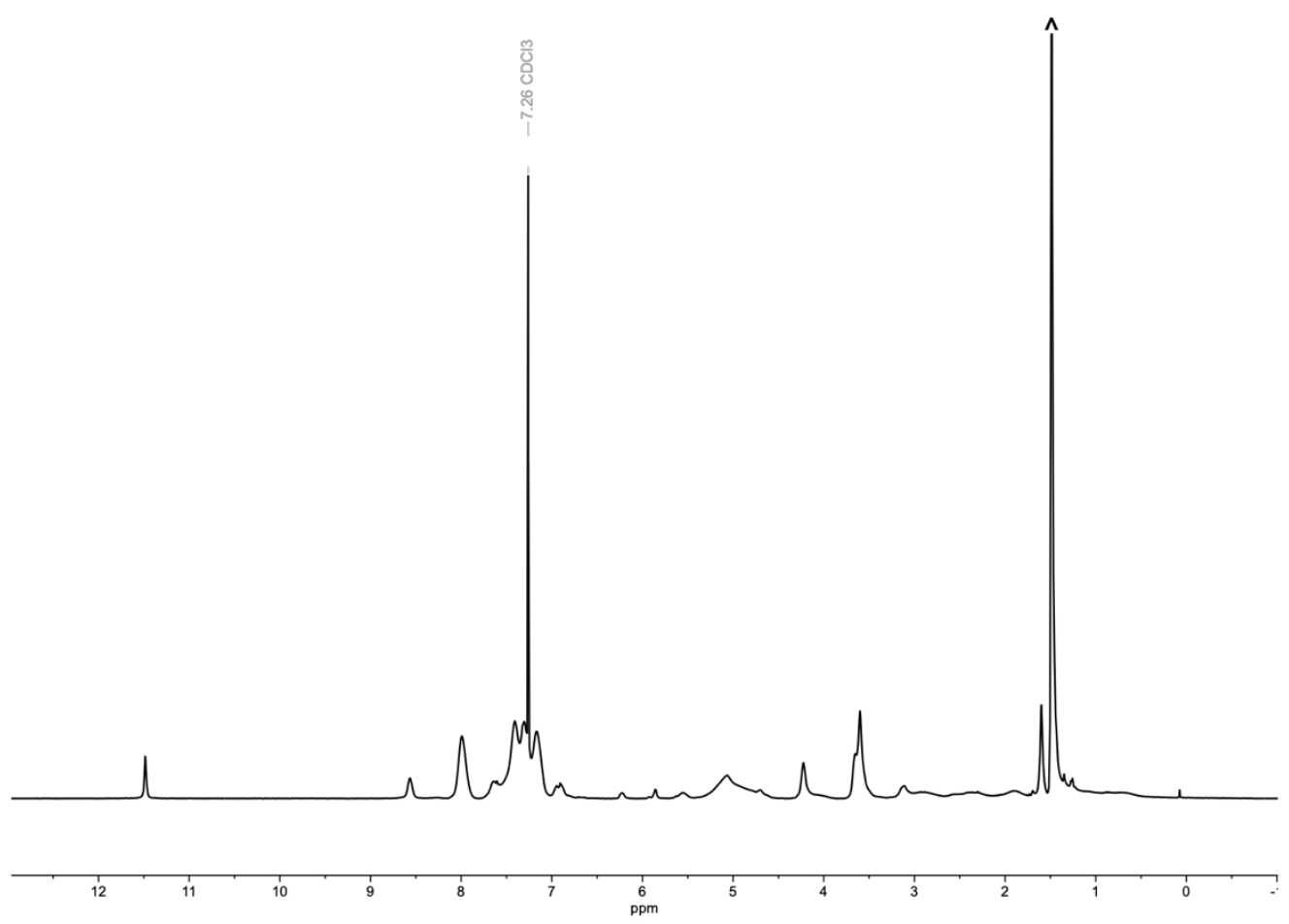

Figure S9. ${ }^{1} \mathrm{H}$ NMR (400 MHz) spectrum of Boc-protected $\mathbf{B G N}_{\mathbf{1 0}}-\boldsymbol{b}-\mathbf{P}_{\mathbf{2 0}}$ in $\mathrm{CDCl}_{3} \cdot{ }^{\wedge}=\mathrm{H}_{2} \mathrm{O}$ 


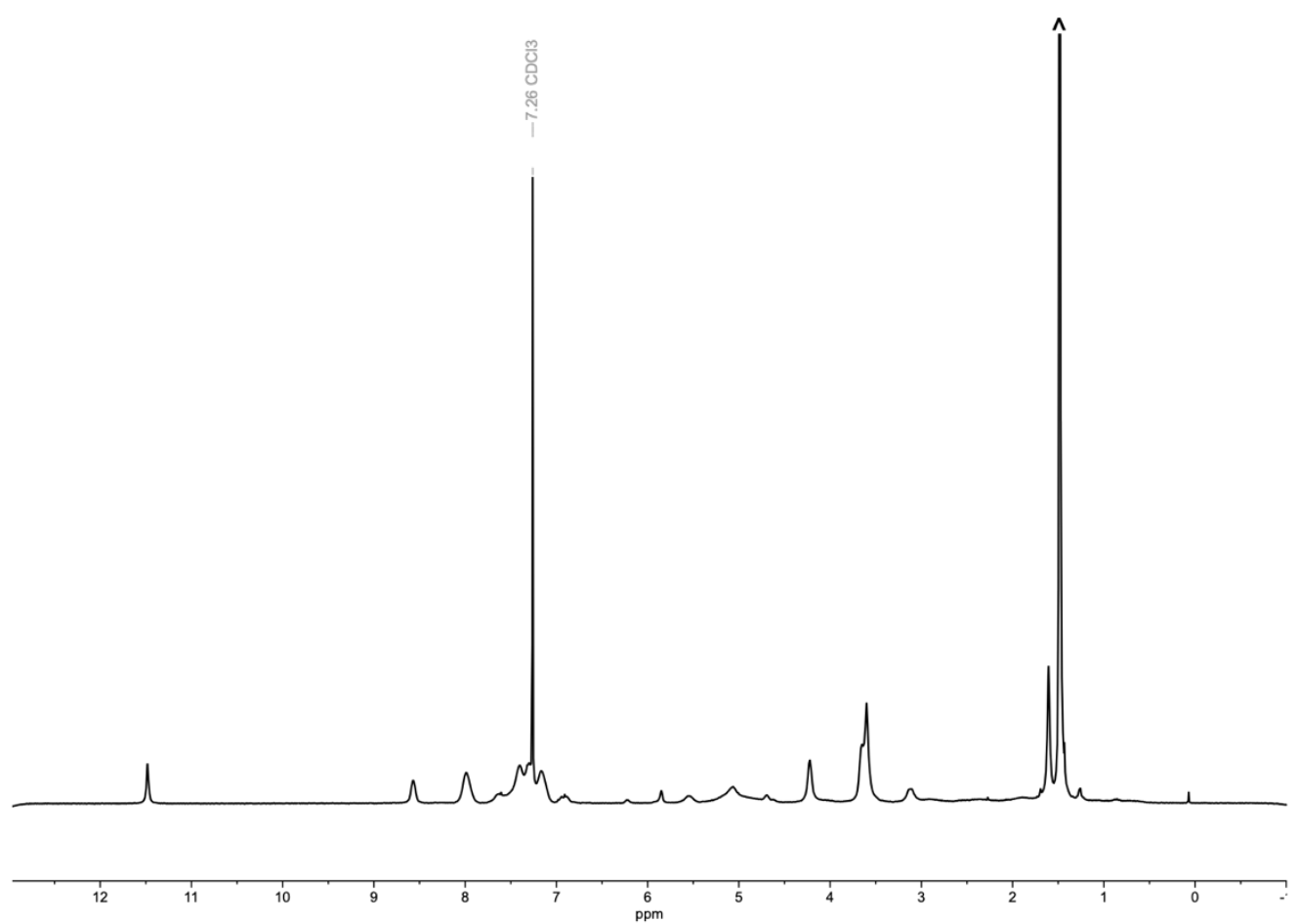

Figure S10. ${ }^{1} \mathrm{H}$ NMR $(400 \mathrm{MHz})$ spectrum of Boc-protected $\mathbf{B G N}_{\mathbf{2 0}}-\boldsymbol{b}-\mathbf{P}_{\mathbf{2 0}}$ in $\mathrm{CDCl}_{3}{ }^{\wedge}=\mathrm{H}_{2} \mathrm{O}$
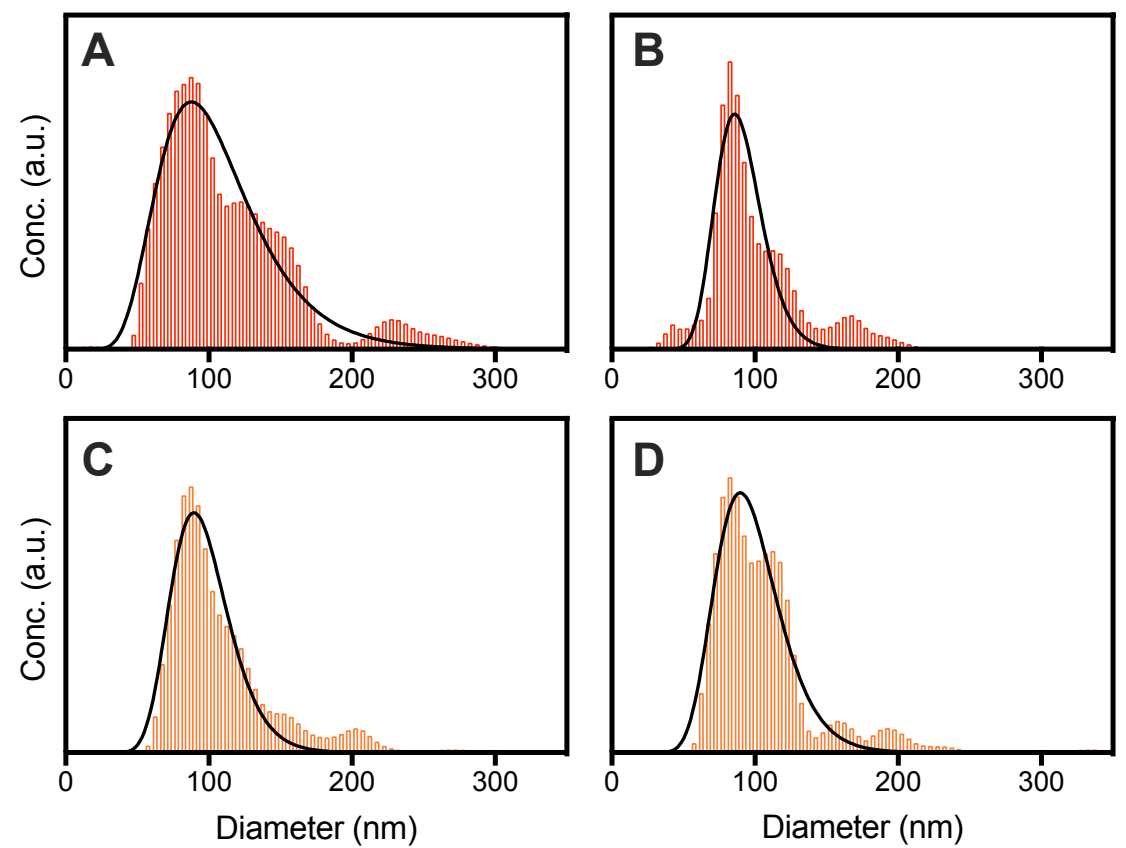

Figure S11. Size distribution of Pdots in aqueous solution at $1 \mathrm{mg} \mathrm{mL}^{-1}$ (bar) and curve fit (solid line). (A) $\mathbf{B G N}_{10}-b-\mathbf{M}_{20}$, (B) $\mathbf{B G N}_{20}-b-\mathbf{M}_{20},(C) \mathbf{B G N}_{10}-b-\mathbf{P}_{20}$, and (D) $\mathbf{B G N}_{20}-b-\mathbf{P}_{20}$. 


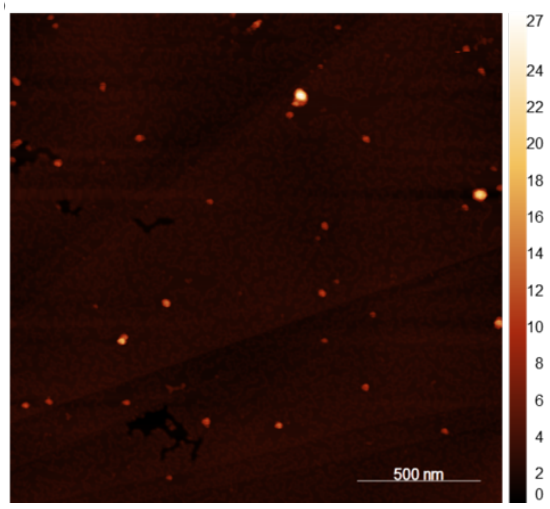

Figure S12. AFM height images of $\mathbf{B G N}_{\mathbf{2 0}}-\boldsymbol{b}-\mathbf{M}_{\mathbf{2 0}}$ Pdots on HOPG substrates. Scale bar $=500 \mathrm{~nm}$.
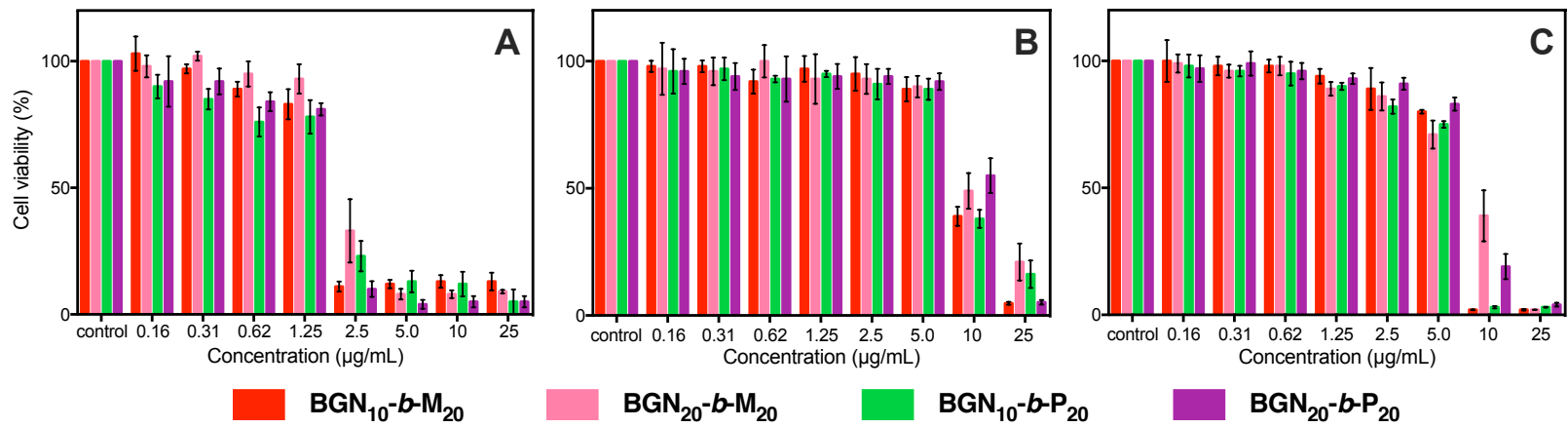

Figure S13. Cell viability of (A) CHO, (B) HeLa, and (C) HepG2 cells after incubation with Pdots for 24 h, measured by MTT assay.
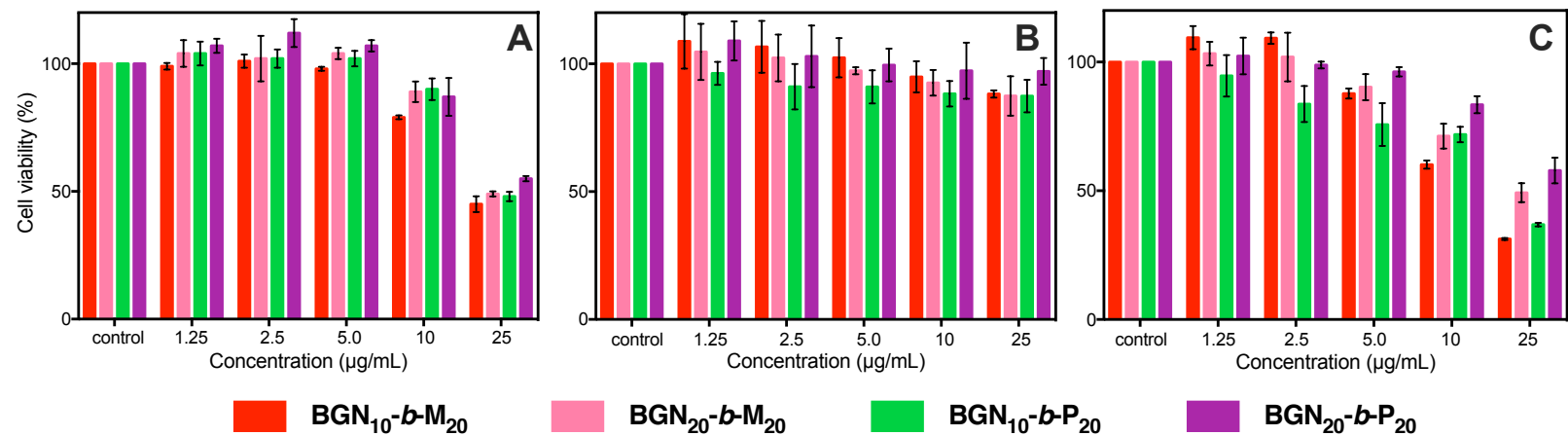

Figure S14. Cell viability of (A) CHO, (B) HeLa, and (C) HepG2 cells after $1 \mathrm{~h}$ incubation with Pdot solutions at varying concentrations $\left(0-25 \mu \mathrm{g} \mathrm{mL}^{-1}\right)$; measured by an MTT assay. 

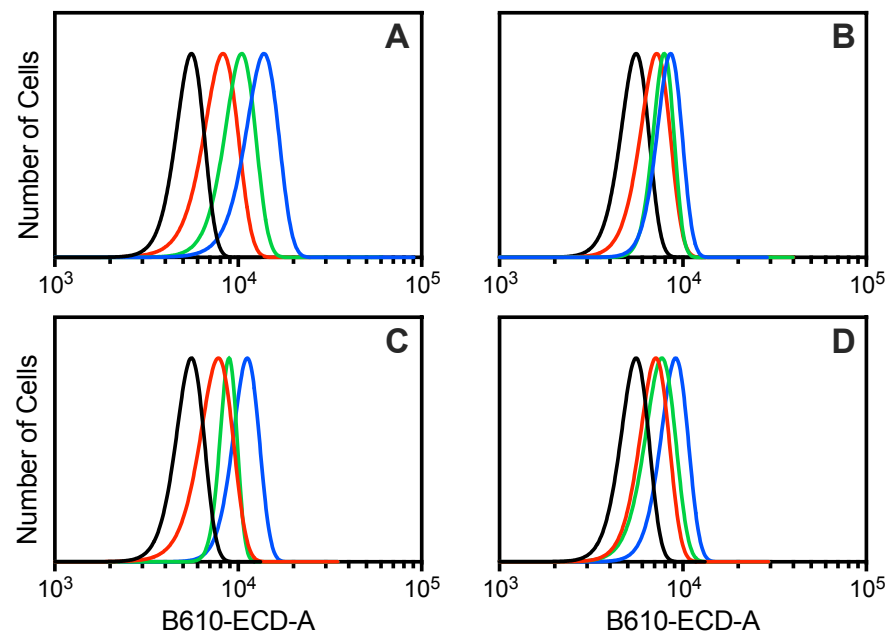

- Control $-5 \mu \mathrm{g} / \mathrm{mL}-10 \mu \mathrm{g} / \mathrm{mL} \quad-25 \mu \mathrm{g} / \mathrm{mL}$

Figure S15. Mean fluorescence of HeLa cells after incubation for 30 min with (A) $\mathbf{B G N}_{\mathbf{1 0}}-\boldsymbol{b}-\mathbf{M}_{\mathbf{2 0}}$, (B) $\mathbf{B G N}_{20}-\boldsymbol{b}-\mathbf{M}_{20},(\mathrm{C}) \mathbf{B G N}_{\mathbf{1 0}}-\boldsymbol{b}-\mathbf{P}_{\mathbf{2 0}}$, and (D) $\mathbf{B G N}_{\mathbf{2 0}}-\boldsymbol{b}-\mathbf{P}_{\mathbf{2 0}}$ Pdots at varying concentrations. Measured by flow cytometry.
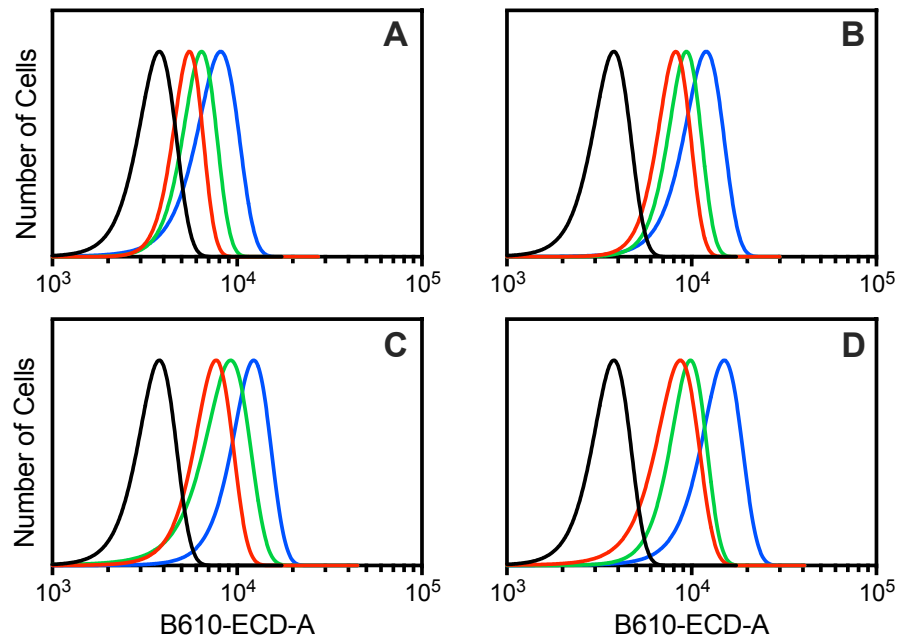

- Control $-5 \mu \mathrm{g} / \mathrm{mL}-10 \mu \mathrm{g} / \mathrm{mL}-25 \mu \mathrm{g} / \mathrm{mL}$

Figure S16. Mean fluorescence of $\mathrm{CHO}$ cells after incubation for 30 min with (A) $\mathbf{B G N}_{\mathbf{1 0}} \mathbf{- b}-\mathbf{M}_{\mathbf{2 0}}$, (B) $\mathbf{B G N}_{20}-\boldsymbol{b}-\mathbf{M}_{20},(\mathrm{C}) \mathbf{B G N}_{\mathbf{1 0}}-\boldsymbol{b}-\mathbf{P}_{\mathbf{2 0}}$, and (D) $\mathbf{B G N}_{\mathbf{2 0}}-\boldsymbol{b}-\mathbf{P}_{\mathbf{2 0}}$ Pdots at varying concentrations. Measured by flow cytometry. 

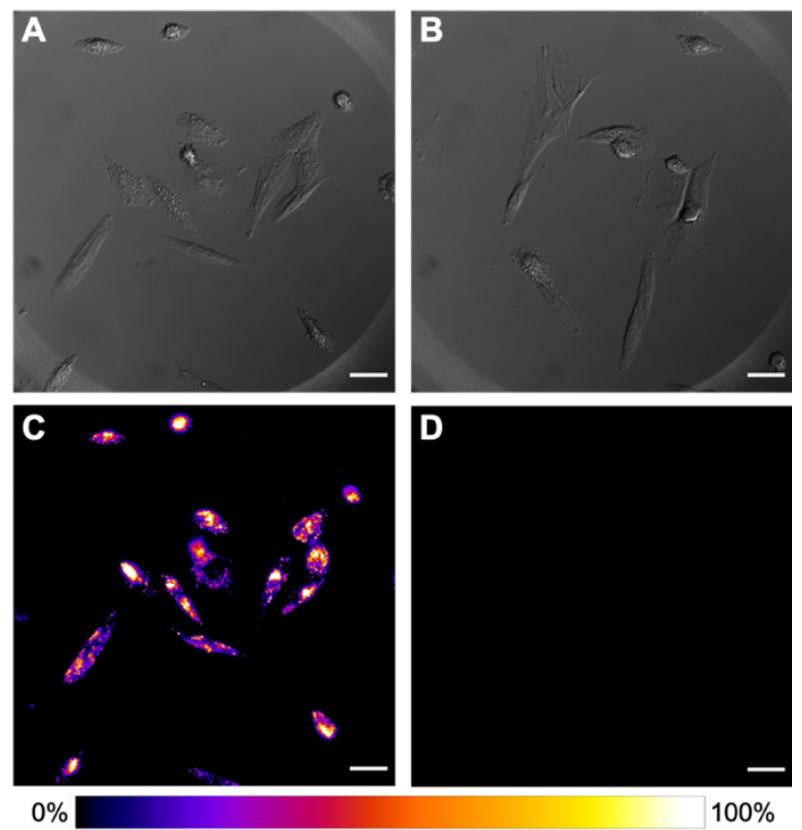

Normalized PL intensity (a.u.)

Figure S17. (A, B) Differential interference contrast (DIC) and (C, D) photoluminescence (PL) images of CHO cells (A, C) incubated with $\mathbf{B G N}_{\mathbf{1 0}}-\boldsymbol{b}-\mathbf{M}_{\mathbf{2 0}}$ Pdots and (B, D) control without any incubation with Pdots. PL images were taken with the same microscope settings and adjusted to the same brightness and contrast. Scale bar $=20 \mu \mathrm{m}$. For image C: $\mathrm{SBR}=2.6 \pm 0.2 ; \mathrm{SNR}=24 \pm 2$ (from 12 cells).
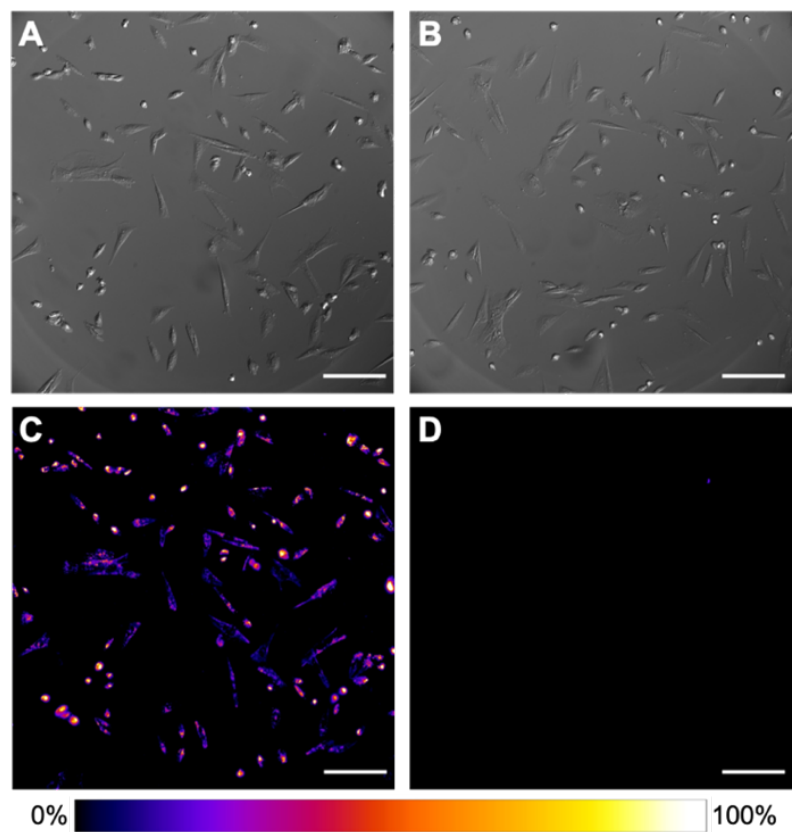

Normalized PL intensity (a.u.)

Figure S18. (A, B) DIC and (C, D) photoluminescence images of CHO cells incubated with (A, C) BGN $\mathbf{~}_{10}^{-}$ $\boldsymbol{b}$ - $\mathbf{M}_{20}$ Pdots and $(\mathrm{C}, \mathrm{D})$ control without any incubation with Pdots. PL images were taken with the same microscope settings and adjusted to the same brightness and contrast. Scale bar $=100 \mu \mathrm{m}$. For image C: $\mathrm{SBR}=3.2 \pm 0.7 ; \mathrm{SNR}=28 \pm 6$ (from 74 cells). 

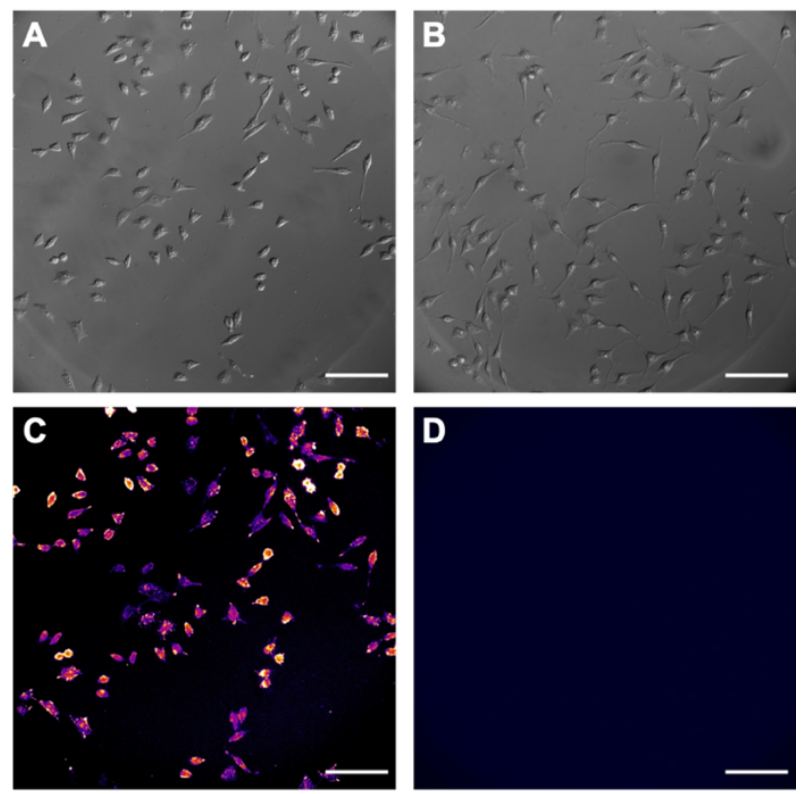

$0 \%$

$100 \%$

Normalized PL intensity (a.u.)

Figure S19. (A, B) DIC and (C, D) photoluminescence images of HeLa cells incubated with (A, C) BGN $\mathbf{B O}^{-}$ $\boldsymbol{b}$ - $\mathbf{M}_{20}$ Pdots and (C, D) control without any incubation with Pdots. PL images were taken with the same microscope settings and adjusted to the same brightness and contrast. Scale bar $=100 \mu \mathrm{m}$. For image C: $\mathrm{SBR}=1.4 \pm 0.1 ; \mathrm{SNR}=16 \pm 1$ (from 63 cells).
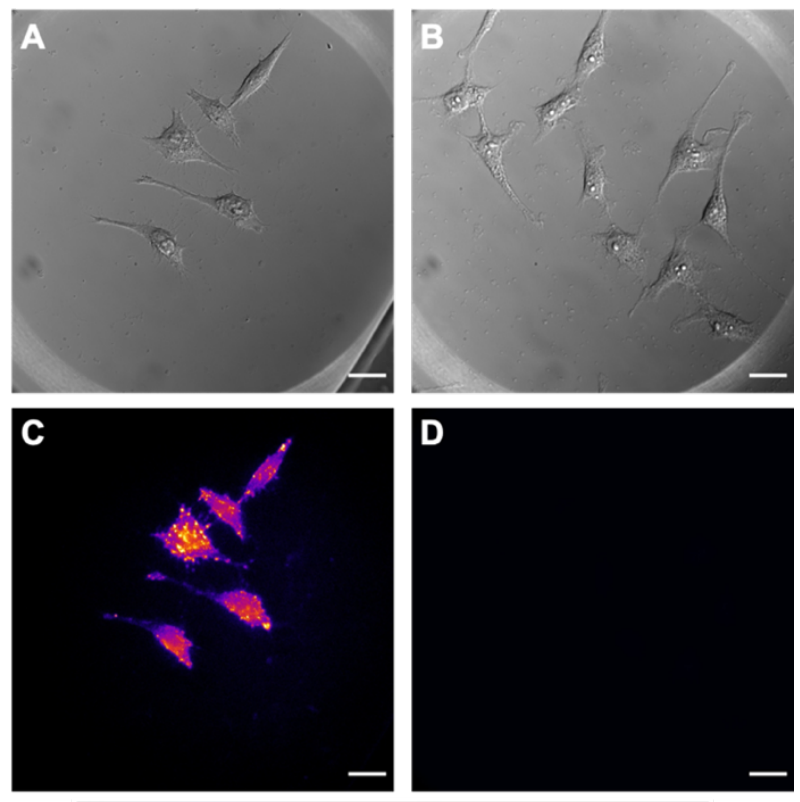

$0 \%$

$100 \%$

Normalized PL intensity (a.u.)

Figure S20. (A, B) DIC and (C, D) photoluminescence images of HeLa cells incubated with (A, C) BGN $\mathbf{~}_{10}$ $\boldsymbol{b}$ - $\mathbf{M}_{20}$ Pdots and (B, D) control without any incubation with Pdots. PL images were taken with the same microscope settings and adjusted to the same brightness and contrast. Scale bar $=20 \mu \mathrm{m}$. For image C: SBR $=1.3 \pm 0.1 ; \mathrm{SNR}=14 \pm 1$ (from 5 cells). 

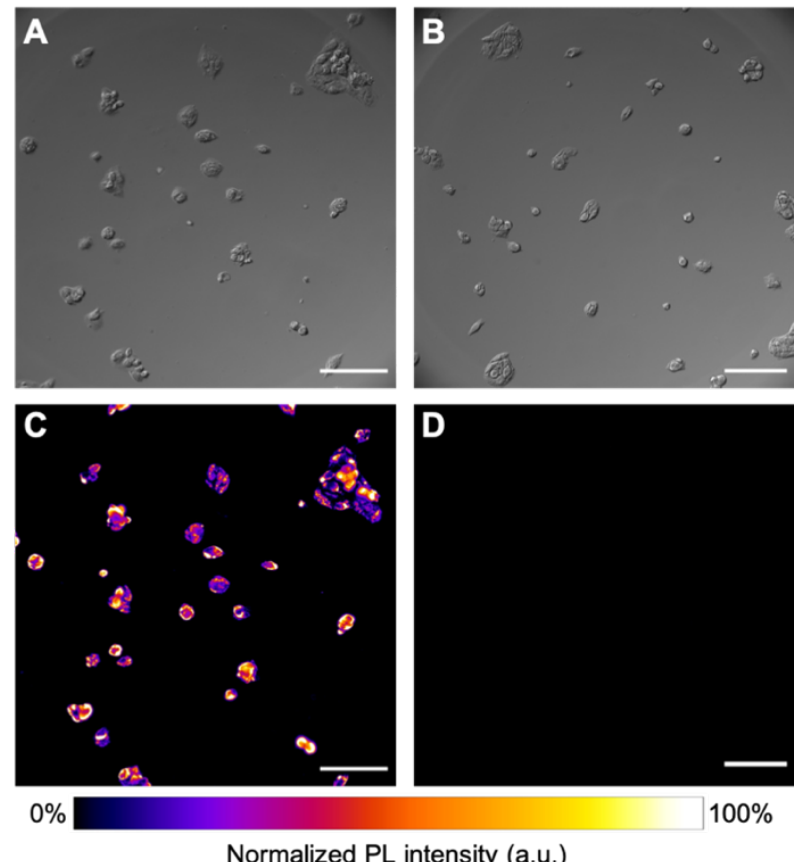

Figure S21. (A, B) DIC and (C, D) photoluminescence images of HepG2 cells incubated with (A, C) $\mathbf{B G N}_{10}-\boldsymbol{b}-\mathbf{M}_{20}$ Pdots and (C, D) control without any incubation with Pdots. PL images were taken with the same microscope settings and adjusted to the same brightness and contrast. Scale bar $=100 \mu \mathrm{m}$. For image $\mathrm{C}: \mathrm{SBR}=2.2 \pm 0.4 ; \mathrm{SNR}=28 \pm 5$ (from 28 cells).

\section{References}

(1) Christopherson, C. J.; Mayder, D. M.; Poisson, J.; Paisley, N. R.; Tonge, C. M.; Hudson, Z. M. 1,8Naphthalimide-Based Polymers Exhibiting Deep-Red Thermally Activated Delayed Fluorescence and Their Application in Ratiometric Temperature Sensing. ACS Appl. Mater. Interfaces 2020, 12 (17), 20000-20011.

(2) Hickey, S. M.; Ashton, T. D.; Pfeffer, F. M. Facile Synthesis of Guanidine Functionalised Building Blocks. Asian J. Org. Chem. 2015, 4 (4), 320-326.

(3) Tezgel, A. O.; Telfer, J. C.; Tew, G. N. De Novo Designed Protein Transduction Domain Mimics from Simple Synthetic Polymers. Biomacromolecules 2011, 12 (8), 3078-3083.

(4) Bolte, S.; Cordelières, F. P. A Guided Tour into Subcellular Colocalization Analysis in Light Microscopy. J. Microsc. 2006, 224 (3), 213-232. 